\title{
Indirection and Character in "Song of Myself"
}

\author{
by \\ Thomas Sorensen \\ B.A. (Hons. English), Carleton University (2011)
}

\begin{abstract}
A thesis submitted to the Faculty of Graduate and Postdoctoral Affairs in partial fulfillment of the requirements of the degree of
\end{abstract}

\author{
Master of Arts
}

in

English Language and Literature

Carleton University

Ottawa, Ontario

(C) 2014

Thomas Sorensen 


\begin{abstract}
:
In the 1980's and 1990's, a number of critics came to the conclusion that Whitman aspired to an unmediated act of poetic self-representation. I revisit this conclusion, arguing that although it is true Whitman considered his poetry an extension of his personality, he also believed personality is ineffable, and as such avoids exposing it to engaged representation. Instead, he proceeds according to his theory of "indirection"--that is, the poem does not represent his personality as such, but rather evokes a vague atmospheric quality meant to approximate the peculiar resonance of his own personality. I inquire into the specific means available to Whitman's indirect method, as well as the challenges indirection presents to dominant reading practices.
\end{abstract}


In its first line, "Song of Myself" is introduced as an expressive act: "I celebrate myself, and sing myself." Later, in "A Backward Glance," Whitman writes, [There] was a feeling or ambition to articulate and faithfully express in literary or poetic form, and uncompromisingly, my own physical, emotional, moral, intellectual, and aesthetic Personality, in the midst of, and tallying, the momentous spirit and facts of its immediate days, and of current America.

Here, Whitman likewise presents his poetry within an expressive paradigm, as an extension of his personality. ${ }^{1}$

With this in mind, it is strange that Whitman denies the "real Me" or "Me myself," presumably his true self or most essential element, representation. Admonishing speech directly, the speaker declares: "Come now... you conceive too much of articulation, / ... / My final merit I refuse you, I refuse putting from me what I really am, encompass worlds, but never try to encompass me" (25.10-19). Although Whitman has profound respect for language, he implies that beyond a certain point articulation would divide him from what he really is. Instead, the Me myself remains elusive and remote, "apart from the pulling and hauling" of life, "both in and out of the game and watching and wondering at it" (4.140).

Whitman seems to be contradicting himself. On the one hand, he frames the poem as a grand manifestation of his inner being. On the other, he withholds the vital core of his existence, claiming it is beyond representation. How can Whitman claim to express himself while denying himself expression? In what follows, I argue that Whitman's poetics of indirection holds the answer to this problem. Whitman believed that everything contains a spiritual essence, a kind of

\footnotetext{
${ }^{1}$ The self is a vague and complex concept in Whitman's writings, and he never clearly defines it. For that reason, my argument focuses primarily on his concept of character or personality, although it is at times necessary to speculate about his conception of the self as well. The distinction between self and personality will be clarified over the course of my argument.
} 
genius or aura latent and implicit in its physical being. The spirit of a thing does not submit to logical categories. It resists expression and representation. A poet can only access it indirectly, by presenting the outer form simply as it is. In his preface to the 1855 edition of Leaves of Grass, Whitman writes, "to speak in literature with the perfect rectitude and insousiance of the movements of animals and the unimpeachableness of the sentiment of trees in the woods and grass by the roadside is the flawless triumph of art" (Leaves of Grass, 499). At first, this might seem very limiting, and those critics who have dealt with indirection in depth sometimes interpret it as such. Howard J. Waskow, for example, postulates that a truly indirect poem would consist of a single long catalogue (63). However, there is considerable evidence that, for Whitman, music, gestures, poems, and even words are themselves natural objects that contain spiritual essences no less compelling than those of living things. Once this has been taken into account, Whitman's theory of indirection becomes considerably more versatile.

Scholarship to date does not sufficiently illuminate the role indirection plays in Whitman's representation of himself. Considering how he is the ultimate object of his own poetry, this question is essential to any understanding of Whitman's poetry and poetics. Within the context of Whitman's theory of indirection, "Song of Myself" can be read as hinting at his own spiritual essence, what he refers to throughout his journals and lecture notes as "character" or "personality." For Whitman, character is a latent fund of spiritual energy that manifests itself only through subtle hints of behaviour and presence, through style rather than signification, manner rather than meaning. Of course, the reader cannot see the poet or hear him speak. The poetic medium is inescapably abstract. However, poetry equips the author with a different but no less effective set of tools, such as poetic style and the music of language, what Whitman refers to 
as the overall "drift" of his poetry. I also follow John Irwin in contending that gesture is a way for Whitman to suggest a special sense of himself without describing or defining it directly.

There is considerable evidence that the elusive figure alternately addressed as the "real Me," "Me myself," or "soul" is the poetic incarnation of Whitman's private character. If so, Whitman's theory of indirection explains why this figure never speaks and is never clearly delineated. I show how Whitman's language becomes less clearly referential when describing the real Me. Aside from a few quick glimpses and blurry outlines, the real Me expresses itself only through a few silent gestures. These gestures do not clearly refer to anything in particular, but evoke only a vague, indefinite quality of movement. Gesture and a subtle, idiosyncratic use of language are two essential means by which Whitman intimates the ineffable character of the real Me.

I build my argument partly in response to a small cluster of work done on Whitman's mode of representation from the 1980's and early 1990's, when deconstruction was at its zenith. Specifically, John T. Irwin's American Hieroglyphics (1980), Mark Bauerlein's Walt Whitman and the American Idiom (1991) and his essay "Whitman's Language of the Self" (1987), James Perrin Warren's Walt Whitman's Language Experiment (1990), and Tenney Nathanson's Whitman's Presence: Body, Voice, and Writing in Leaves of Grass (1992). These works reached some conclusions that I would like to revisit—namely, that Whitman aspired to an unmediated or consummate representation of himself. Irwin argues that Whitman creates a poetic self constituted in and by the poem, so that when the poem refers to Walt Whitman, it actually refers to itself, circumventing any form of mediation. In "Whitman's Language of the Self," Bauerlein contends that Whitman tries to exteriorize himself through poetry, but ends up projecting only a 
shadowy ideal image that reminds him of his own shortcomings. Warren focuses mainly on Whitman's philosophy of language. He sees Whitman as attempting to reconcile signifier and signified in order to manifest himself and other objects on the page. Nathanson argues that Whitman uses verbal devices to conjure his poetic presence, closing the gap between reader and writer. There are two main issues common to all five studies I would like to consider. The first concerns Whitman's language philosophy. These scholars claim or at least suggest that Whitman sought to collapse or obviate the distinction between word and referent. A closer analysis, however, will reveal that Whitman's theory of language was considerably more nuanced. Second, and more fundamentally, these critics do not adequately address the problem of Whitman's evasiveness. The self in Leaves of Grass wavers between a universalized identity that inhabits a fluid succession of masks, and a sequestered, mysterious, self-contained individuality, each of which resists representation in its own ways: the I is too protean and formless, the $\mathrm{Me}$ myself too mysterious and withdrawn. These critics do not sufficiently account for the lengths to which Whitman avoids the spotlight of his own poetry.

Mark Bauerlein and Tenney Nathanson tend to follow what Stephen Best and Sharon Marcus term a "symptomatic" (3) approach to criticism. That is, they seek to uncover hidden contradictions and tensions the text represses. Over the course of my analysis, I will show how these symptomatic readings are based on an expressive paradigm that does not necessarily apply to Whitman's poetry. Instead, I argue that Whitman has rethought, to a certain extent, the traditional relationship between form and meaning. The truly indirect text is not a symbolic code that, once cracked, yields a kernel of profound insight. Instead, meaning is, ideally, apparent at face value. As such, Whitman's poetry yields more readily to a "surface reading" method, which 
seeks to develop alternative reading methods outside the surface-depth dichotomy. I do not mean to question the validity of symptomatic approaches. However, I am interested in how "Song of Myself" presents challenges to the discipline of literary criticism as it is currently entrenched in a symptomatic methodology. ${ }^{2}$

Once I have addressed these issues, I show that only within the context of Whitman's theory of indirection can he insist that the poem represents him while denying himself representation. I begin by defining Whitman's theory of indirection. I then explore Whitman's ideas on character, heavily influenced by Emerson's essays. Then, once I have established that the real Me stands for Whitman's inner character, I conduct an in-depth analysis of several key passages in which the real Me/Me myself makes an appearance. I show how Whitman, when describing the real Me, uses gesture and language in such a way that they do not clearly refer to any direct meaning in particular, but rather evoke a peculiar impressionistic quality that is meant to suggest subtle traces of Whitman's indefinable character.

The most recent inquiry into Whitman's method of representation is Peter Bellis's Writing Revolution. Although I agree with much of what Bellis says, his premises are undermined by challenges already presented by earlier research. For example, he argues that "If the notion of representation implies a loss or substitution for an original no longer present, Whitman's verbs —_enclose,' 'reception,' 'responds,' 'incarnates' —insist on that physical presence” (78). In other terms, every written word stands for something out there in the world that is not present.

\footnotetext{
2 Surface reading is still in an early, experimental stage. As such, I do not strictly adhere to the surface of the text. I occasionally delve into the depths as well, exploring possible hidden meanings. Whitman himself seems to have been wary of inhibiting his own creative impetus out of fidelity to any rigid principles, even his own, and as a result can often be seen deviating from his own poetic philosophy. In general, I am interested in how Whitman's poetry seems to encourage a surface-reading approach. For more on surface reading and related approaches, see Anne Cheng, "Skin, Tattoos, and Susceptibility," Heather Love, "Close Reading and Thin Description," and Sharon Marcus, Between Women: Friendship, Desire, and Marriage.
} 
Whitman's verbs insist that the object is present. This argument is anticipated by Nathanson. Nathanson too argues that Whitman denies the absence of the referent, but he concentrates on how these referents fail to materialize nonetheless: "the poet's claims that he speaks to us 'here' and 'now'... trope such experience rather than simply reproducing it, creating the magical, virtually omnipotent voice that seems to speak in Whitman's poems" (11). In order to advance any further, Irwin, Bauerlein, Warren, and Nathanson will have to be reckoned with. I respond briefly to Warren in my section on Whitman's language philosophy, and to John Irwin in the section on character, since his approach is considerably different from the others. I will start with Bauerlein and Nathanson.

My response to Bauerlein focuses mostly on his essay, "Whitman's Language of the Self" because I am mainly concerned with how Whitman represents himself, while Walt Whitman and the American Idiom deals mostly with Whitman's language philosophy. In his essay, Bauerlein argues that Whitman is trying to manifest himself on the page as accurately as possible. However, the poet's medium is language, and words are abstract and arbitrary. As a result, Bauerlein's Whitman succeeds only in projecting a remote, idealized self-image that makes him all the more aware of his own inner conflicts:

While Whitman longed to exteriorize his self, to signify his desires in a transparent medium that would preserve the ego's primacy and integrity, the opposite occurred. Instead of Whitman structuring his poetry along the lines of his free, transcendent identity, the poetry structured Whitman's identity along the lines of figurative conventions." (146) 
Considered along these lines, Leaves of Grass plays out Whitman's struggle to deliver a poetic embodiment of himself. Since Whitman is working in an abstract medium, this struggle is ultimately doomed to failure.

One major obstacle Whitman has to overcome, Bauerlein argues, is the arbitrary relation between word and referent. According to Bauerlein, Whitman tries to circumvent this obstacle by attributing a spiritual tie between language and character: "the obvious way to obviate the alienating separation between a subject and the words it uses to manifest itself is to assert a mystical connection between the two" (135). Bauerlein does not define what exactly this mystical connection is in his essay. He only implies that words, for Whitman, can somehow embody or capture inner being: "That words could materialize "character" while still partaking in its "spiritual" nature Whitman believed all his life" (135). However, in his book, Whitman and the American Idiom, Bauerlein develops his interpretation of Whitman's language philosophy in greater detail. He argues that Whitman "postulates an organic connection between word and thing... and a mimetic or expressive relationship, without distortion, between world and desire" (22). For Bauerlein, Whitman tries to reclaim an "Adamic language" (26) in which sign and thing are consubstantial in an attempt to realize an unmediated form of expression. Although there are passages in Whitman's language philosophy that seem to suggest as much, I will show that these passages also yield to another, more plausible interpretation that is more consistent with Whitman's theory of indirection. ${ }^{3}$

Another way Whitman avoids the arbitrariness of language, according to Bauerlein, is by not using it. Whitman often uses gesture and "the silent look" (139) without describing or

\footnotetext{
${ }^{3}$ Bauerlein focuses on Whitman's earlier work. He argues that Whitman later revised his ideas about language and representation.
} 
expressing himself in words: "The spiritual communication Whitman envisions transcends both written and spoken words and sounds and so he opts for a meaningful silence, a significant 'hush' endowed with value by Whitman's expressive physiognomy” (139). On this point, Bauerlein comes very close to contradicting his own thesis. His argument boils down to the following line of reasoning: Whitman tries to represent himself in language. But language is abstract. To avoid this problem, Whitman does not represent himself in language. Bauerlein tries to resolve this contradiction by reminding the reader that Whitman does in fact use words: "But of course, Whitman must use words. The placid exterior of nature... may constitute a poem for Whitman, but he cannot rewrite it or use it as a paradigm of creation without the supervention of language" (142). It is true that Whitman cannot use nature in poetry "without the supervention of language." But in order to make his point, Bauerlein needs to show that Whitman uses language to define himself.

In an attempt to do so, Bauerlein points out that nature exists beyond language. It is not split between what it is and what it wants to be. Nature, therefore, is perfect, consummate, whole. And this perfection, according to Bauerlein, makes Whitman feel divided and inadequate. Bauerlein's Whitman tries to overcome this sense of deficiency by manufacturing a coherent self-image from writing: "Nature becomes an antagonist, an archetypal author and expression... whose peremptory wholeness only reminds Whitman of his deficiency. Had not Whitman sensed a lack, an absence, with the concomitant desire, he would have felt no urge to write" (142). However, this amounts to circular reasoning: Whitman writes to compensate for a sense of lack, and we know he felt this lack because he writes. There is no firm evidence that Whitman felt this deficiency, and so there is no reason to suppose that he tried to compensate for it through writing. 
As such, the problem remains: there is not enough evidence to suppose that Whitman's ultimate goal is to exteriorize himself.

Tenney Nathanson joins Bauerlein in arguing that Whitman sought to materialize himself through poetry. Whitman's primary strategy, for Nathanson, operates through the power of the voice. Basically, Nathanson observes that writing always refers to something that is not there. Speech, however, implies presence. A person must be nearby to be heard. According to Nathanson, Whitman creates an illusion of presence with verbal devices not commonly used in writing. Among the devices Nathanson identifies are performatives, which "make something true by virtue of declaring it" (6), and apostrophe, the direct address of the reader by the author. These devices create the unsettling quality that Whitman is in the room as we read: "we are caressed, as it were, by a phantom" (3).

There is nothing wrong with Nathanson's argument at this stage. It is true that Whitman uses plenty of verbal devices, and it is plausible to suppose that they create an illusion of presence. The problem is that Nathanson takes his reading to somewhat of an extreme, claiming that Whitman did not think the illusion of presence was entirely an illusion. Nathanson explains that Whitman believed in the indivisible union of word and referent: "throughout his early work, Whitman aspires to the word magic of the shaman: the sense of words the early poems seek to convey has... the archaic belief in the magical power of naming" (6). According to Nathanson, Whitman believed that a word is linked to some inherent element of what it refers to. If so, the word has the power to bring about the poet's presence as well: "In the magical universe of Leaves of Grass the poet himself is the key instance of such fusion [between word and referent]: 
the word that announces him to us does not simply stand for the poet's presence but apparently produces and is indeed part of it" (7).

In brief, Nathanson argues that Whitman tries to bestow magical incantatory powers to language and associates voice with presence in an effort to make himself literally present through his poetry. ${ }^{4}$ As such, he contends that Whitman attempts to bring about an unmediated act of representation. That said, Nathanson's argument turns upon the premise that Whitman believed in the organic union of words and things. But if Whitman did not entertain the possibility of ever recovering an Adamic state of language, it would be unreasonable to suppose that he attempts to manifest his presence through writing.

As with Bauerlein, Nathanson's reading leads to a sadly mistaken Whitman relentlessly trying to realize the impossible. Nathanson points out several fundamental flaws in Whitman's approach that prevent the materialization of presence through the voice. First, Whitman is not actually speaking. He is writing, and writing does not imply or produce presence. For this reason, Nathanson sees Whitman as constantly trying to hide the fact that Leaves of Grass is a written text:

Writing... re-presents words spoken in another place and time and offers us only the representations of the actual presence to which speech attests. Writing thus comes to represent all that separates the poet from his divine origins: dramatically detaching his presence from his word, it consigns him to an ordinary body and leaves his language plainly bereft of the productive, performative power to which

Whitman aspires.

\footnotetext{
${ }^{4}$ Nathanson draws a distinction between the author's literal bodily presence and a sort of ideal, immaterial presence. It is this ideal presence that is incarnated in the word. For more details, see Nathanson 114-119.
} 
So for Nathanson, when Whitman declares, "Camerado! This is no book, / Who touches this, touches a man" ("So Long!" 2.45), he is urging the reader to overlook the poem's textuality, allowing for an unmediated engagement with the speaker's voice. Writing, for Nathanson, is an embarrassing malfunction that Whitman constantly tries to cover up. Another obstacle that impedes the magical transmission of the speaker's presence is that words are not really consubstantial with their referents, and as such cannot bring about the things they name: "If writing palpably fails to convey the presence the poet's voice seems to generate, that is because it manifests starkly limitations that lurk in oral language as well... Foremost among these faults is the gap between the sign and its referent, the word and the thing itself" (14).

One issue Nathanson's argument does not entirely resolve is that the real Me does not speak. Whitman deliberately excludes his most essential element from the power of the voice. Nathanson comes closest to addressing this issue in his analysis of section $28,{ }^{5}$ where Whitman denies himself representation in language. Nathanson argues that the presence of the speaker, despite Whitman's disavowal, is itself a product of words and voice: "this hovering but unlocatable figure who cannot be 'proved' by mere 'talk' is evoked by and modeled on voice. The silent body praised in Leaves of Grass is a body defined by speech" (152). Although it is true that the persona speaks, I do not see how this makes him a product of language. There is a difference between using words and using words to define oneself. Whitman often describes

\footnotetext{
5 Nathanson quotes the 1855 version (151). Whitman addresses speech directly:

Encompass worlds but never try to encompass me, I crowd your noisiest talk by looking toward you.

Writing and talking do not prove me, I carry the plenum of proof and everything else in my face, With the hush of my lips I confound the topmost skeptic.
} 
other things, but he rarely subjects himself to any engaged description. Whitman would have to put himself directly into language to bring about his presence through word magic, and he specifically avoids doing any such thing. Furthermore, Nathanson makes no distinction between the speaking persona and the real Me. Throughout Whitman's poetry, the real Me makes no use of words. Nathanson admits that those sections in which the real Me makes an appearance seem to be at odds with the program he attributes to Whitman: "Partly a melancholy intimation of the divided status of the subject, such distant images of self-contained identity... serve to suspend the uncomfortable consequences of the poet's imperial energies" (399). He passes them over as an unreconciled strain: “despite such demurs, the poem's first five sections tend to center power and authority on the poet." Nathanson cannot adequately account for the silence of the real Me.

Bauerlein and Nathanson paint similar portraits of a conflicted but tenacious Whitman in the early stages, nagged at the back of his mind by inconsistencies he is too absorbed in his own exultation to confront. Both scholars argue that Whitman fails to realize a consummate act of self-expression because he is fundamentally mistaken about the arbitrary nature of linguistic reference. This position is founded upon a misinformed interpretation of Whitman's poetic philosophy. First of all, it is not clear that the expressive paradigm applies to Whitman in the first place. Although there are several instances where Whitman does refer to his poetry as selfexpression, there are just as many passages where Whitman explicitly denies himself representation altogether: "Writing and talking do not prove me / I carry the plenum of proof and every thing else in my face, / With the hush of my lips I wholly confound the skeptic" (25.20-22), or "Why even I myself I often think know little or nothing of my real life, / Only a few hints, a few diffused faint clews and indirections / I seek for my own use to trace out 
here" (When I Read the Book, 5-7). If "Song of Myself" plays out Whitman's struggle to externalize himself in words, why does Whitman never represent himself directly? Why does Whitman allow himself to manifest only in a universal identity that is indistinct in its diversity, or a hidden and ineffable uniqueness? Neither Bauerlein nor Nathanson adequately address this issue.

This brings me to a second problem common to both Bauerlein and Nathanson, which concerns Whitman's language philosophy, most of which is contained in the two short volumes Words and The Primer of Words, ${ }^{6}$ the essay "Slang in America," and two chapters he may have ghostwritten for his acquaintance William Swinton in Rambles Among Words. At times, Whitman does seem to be positing a mystical connection between words and their referents. However, as I will show, Whitman's philosophy was considerably more nuanced and plausible than Bauerlein and Nathanson recognize.

Nathanson points to several passages throughout Whitman's philosophical writings and poetry that seem to argue for a restored connection between the linguistic sign and its referent. According to Nathanson, "the characteristic task of Whitman's 'great soul' is precisely the recovery of a lost organic tie between word and thing; he is to rescue language from the degraded state in which the connection between them seems to be merely a matter of social convention" (199). Nathanson places Whitman in a tradition of Christian metaphysical linguistics that sought to return to an Edenic state of language when Adam first spoke the true names of all things. John Irwin provides an account of this tradition:

\footnotetext{
${ }^{6}$ The Primer of Words was later published in an altered form under the title, An American Primer.
} 
The metaphysical interpreters worked in a Christian tradition that considered man's present state to be the result of a fall from original simplicity. In his unfallen state man did not need a complex, abstract language. He was in such harmony with his environment that he used the language of nature, of natural signs - that world of objects created by God to stand as emblems of spiritual facts. But since the fall was from simplicity to complexity, the farther man moved from his original state, the more complex and involved his language became, and the more obscure became the old emblematic relationship between a sign and its referent. (7)

Before the fall, Adam and Eve communicated using a language of nature in which there was no gap between word and referent. Words harmonized with the things they named. After the fall, language became progressively more abstract. First, words at least sounded like their referents. Then, through repeated use over thousands of years, words retreated further and further into abstraction, until they reached the arbitrary state of today. Nathanson argues that Whitman wants to return to this original Adamic state of language.

There are two points I would like to address. First, as Nathanson himself points out, Whitman explicitly denied that such a recovery of origins is possible. In his essay, “America's Mightiest Inheritance," Whitman writes, "Language cannot be traced to First Origins. - Of the first origins of language it is vain to treat, any more than of the origin of men and women, or of matter, or of spirit" (quoted in Nathanson, 56). Nathanson has no way of accounting for this inconsistency. He leaves it as an unresolved contradiction, arguing that the rest of Whitman's writings $d o$ set out in search of a recovery of origins. 
This brings me to the second issue in Nathanson's argument. His interpretation relies upon several key passages in which Whitman seems to argue that each name ought to refer exclusively to a single person, place, or thing. If each name referred to one thing and one thing only, name and thing would be indistinguishable:

In the magic that lurks here, words being reserved for a single occasion, and naming a single object, should cease being mere designations, sharing the qualities and attaining the quiddity of what they name. In Whitman's language theory words treated as if they were things become consubstantial with them; the word used properly conjures up the presence of the object with which it is fused (208).

Nathanson then invokes Derrida to show how this leads to the sense that the uniqueness of the word is somehow derived from the uniqueness of the thing: "[one sign to one thing] supposes that there might be... something like a unique sign for a unique thing, a supposition contradictory to the very concept and operation of the sign." If the character of the word somehow reflects that of the referent, Nathanson argues, this suggests that "the thing itself can be made present in and by the word." Nathanson claims that Whitman opposed synonymy in an effort to fuse language and nature.

Nathanson attributes this position to Whitman on the basis of the following passage: "Names of cities, islands, rivers, new settlements, \&c. These should / must assimilate in sentiment and in sound, to something organic in the place, or identical with it" (Words, DBN 3:705). As Nathanson points out, Whitman does seem to think a name is more fitting if it reflects some inherent aspect of the scene: "attentive to the individual entity, the proper name should 
express something inherent in it rather than foisting an alien structure upon it" (Nathanson, 202). Indeed, the idea that a name should "assimilate" features of the locale suggests that names have the power to embody intrinsic characteristics. However, the only intrinsic features Whitman explicitly identifies are "sound" and "sentiment." The idea that the sound of a word might reflect the sounds of a place is not so farfetched. It is possible for a word to capture (through onomatopoeia, for instance) the sounds commonly heard in a particular setting. And "sentiment" only suggests that names should somehow reflect the feelings associated with a place. There is nothing magical about this. People do associate feelings with places and with words. In itself, this quotation provides no substantial evidence that Whitman posited a mystical connection between name and thing.

Furthermore, this passage refers specifically to names of "cities, islands, rivers," and “new settlements," not language as a whole. In order to progress any further, Nathanson's argument must establish that Whitman's theory of names applies to words in general:

“[Whitman's] vision of semantics is implicitly governed by this determination of the truly proper name as the proper mode of language... a vision of absolute uniqueness and propriety somehow to be sustained in and by the word" (205). However, the passages he cites to establish this link are too ambiguous to provide his claims adequate support:

One beauty of words is exactitude:- To me, each word out of the that now compose the English language, has its own meaning, and does not stand for any thing but itself - and there are no two words are the same and any more than there are two persons the same (206).

Nathanson interprets this to mean that "no two words are to possess overlapping meanings." 
However, it is possible to read this passage another way. People commonly think of words as just a way to communicate. From this perspective, a word refers only to the particular thing in mind. The word "gross" means "disgusting" or "big" or "excessive," depending on what is described. I think Whitman is trying to make us think of words as Swiss army knives of signification. A word is not just a particular sign we use to designate a particular thing at a particular moment. "Gross" means "disgusting" and "big" and "excessive." A word contains a plurality of meanings, associations, connotations, and images, all woven together in a bristling texture. From this perspective, each word is unique just as every person is unique. Although, like people, words can resemble and derive characteristics from one another, no two words are exactly alike.

This interpretation resolves inconsistencies Nathanson neglects to address. Nathanson takes this passage to assert that words ought to have only one meaning — that is, it is better for each word to mean exclusively one thing. The problem is that Whitman is describing the present state of the English language: "each word... that now compose[s] the English language" (my emphasis). Whitman is not describing an ideal state of language to be recovered, but the way English currently operates. And it is safe to assume that Whitman knew there are plenty of synonyms in the English language.

Furthermore, Whitman writes that a word "does not stand for any thing but itself." This directly contradicts Nathanson's interpretation. If each word referred to only one thing, it would stand for something other than itself-its referent. This statement only makes sense if we conceive of words as complex constellations of meanings and associations rather than abstract substitutes for real things. Whitman is trying to remind us that a word has a life of its own 
outside any particular act of reference. It is a sequence of sounds or letters. It is associated with images, feelings, and memories. It changes over time. Considered from this perspective, a word can, in a sense, be said to stand only for itself in the same way that a rock or a leaf stands only for itself. Words can be used as signs, but their lexical properties do not define them entirely as such.

My interpretation reconciles one more important inconsistency: Whitman appears to have approved of semantic diversity. Whitman cut the following quotation from a book or article on language philosophy and pasted it into Words, suggesting that he meant to incorporate it into his own language philosophy:

If it be a sign of richness in a language that a single word is used to express many quite different things, the good old English may be regarded as the Rothschild of languages. For instance, how many significations lie in that single monosyllable box? (Daybooks and Notebooks, 684).

Nathanson himself observes that "nothing surrounding the extract expresses disapproval" (206). This is strong evidence that Whitman considered diversity of meaning a sign of richness. Nathanson can only account for this contradiction by distinguishing between Whitman the "practical student of contemporary linguistics," and Whitman the visionary, who got somewhat carried away by his own philosophy: "Repudiating such slippage, Whitman in his visionary guise commits himself instead to the Utopian project of making words themselves exhibit—and thus perhaps sustain,-—perfect distinctness and autonomy” (207). Nathanson suspects that Whitman alternated between two contradictory opinions. Although Whitman's views did change over his lifetime, it does not seem likely that he would vacillate so rapidly and so often between two 
extremes. Only if we read Whitman as trying to formulate a holistic theory of language does it make sense that he would simultaneously affirm the uniqueness of each word and praise diversity of meaning in singular words.

All in all, there is little reason to suppose that Whitman did believed the primordial tie between word and world could be restored. If so, it might be misleading to read "Song of Myself" as Whitman's attempt to manifest his presence through the power of the voice. Similarly, Bauerlein's theory that Whitman asserted a mystical tie between words and things in an effort to avoid abstracting himself in language is inconsistent with Whitman's language philosophy. A more in-depth analysis will reveal that Whitman tries to reconceive of words not as a means for engaged representation, but as actual things in themselves that play off one another in interesting ways.

That Whitman conceived of words as integral bodies of meaning is further supported by several other passages scattered throughout his philosophy of language. However, like Nathanson, critics often read these passages as affirming the indissoluble union of words and referents. On the first page of the Primer of Words, for instance, Whitman asserts that "a perfect user of words uses things":

A perfect user of words uses things... they exude... in power and beauty from him—-miracles from his hands—miracles from his mouth... lilies, clouds, sunshine, woman, poured consciously — things, whirled like chain-shot—rocks, defiance, compulsion, houses, iron, locomotives, the oak, the pine, the keen eye, 
the hairy breast, the Texan ranger, the Boston truckman, the woman that arouses a man, the man that arouses a woman. (42)

Like Nathanson, Joseph Penn Warren reads this as asserting that "thing and word are one" (32), that a word $i s$ its referent. However, I believe Whitman's view is considerably more nuanced. Whitman does not necessarily indicate that a perfect user of words somehow restores signs organically to meaning. Whitman rather seems to suggest that there are two ways to use words: as signs and as things. Words are, as already observed, very diverse. But people tend not to employ the full diversity of words in every-day usage. We tend to invoke words for a single meaning only. This practice drains words of vitality. A perfect user of words activates a word's entire nervous system, bringing it to life in a full-bodied texture of significance. This more sensitive engagement treats a word as a thing because it is no longer just a way of communicating, but is invoked for the manifest character of the whole.

When used as things, words convey a peculiar sense of character. This is what I think Whitman means when he refers to a word's "distinctness," or the "individuality" of a language:

The vitality of speech manifests itself in a two-fold manifestation: in the possession of a distinctive personality and identity—in material elements and formal laws that stamp it with the stamp of linguistic individuality; and, further, in that other characteristic of every living organism -in the exhibition of growth, process, decay —in the ongoing processes of absorption, assimilation, and elimination —in the inworking and outworking of the creative energy (quoted in Warren, 22). 
As words evolve through "the inworking and outworking of the creative energy" of a nation, they gradually accrue new meanings, qualities, and associations that confer a distinct sense of personality or identity upon the word as a whole.

Rohn S. Friedman shows how words gradually acquire a sense of character as they develop a rich and complex history: "Each subsequent use of the word add[s] a fresh possibility to the meaning. Etymology enriche[s] vocabulary not by restricting words to their original meanings, but by allowing the user of words to tap the vast accrued meanings absorbed in each word" (443). Every time a word is used, it acquires new meanings, new associations. The longer a word circulates within an idiom, the more complex it becomes. A talented poet can tap into the full wealth of meaning every word contains. From this perspective, Whitman's position is actually considerably different from that of the metaphysical interpreters, as described by Irwin above. The metaphysical interpreters believed that the more a word is used, the more it is corrupted from an original simplicity. Whitman, on the other hand, considers the history and complexity of language an asset, since it makes words more meaningful.

Whitman cut the following paragraph out from somewhere and pasted it into Words. There is no indication of where the clipping came from. However, the fact that he pasted it in his notebook is significant in itself:

Names have mnemonic power; a vocabulary of their meanings would be as sweet as the songs of the Troubadors. It would be like breaking into old royal tombs, the laying bare of old battle fields, the disclosing of old fossils. We should wonder how much of poetry, of history, of biography, may be wrapped up in a couple of 
syllables... that word 'dilapidated' - it would take the happiest day that Angelo ever saw to paint it (Daybooks and Notebooks, 684).

This passage clearly illustrates the idea that words are more than just abstract signifiers. Each word has a vibrant history, evokes a train of imagery so vivid that it would take Michelangelo at peak condition to paint a particularly vibrant word. The overall effect of the word "dilapidated" is not constituted so much by its conceptual value, the author indicates, as the images it brings to mind. Just as an old house is said to have more character than a new one, the personality of a word is deepened and cultivated over time.

Whitman believed that, over the course of centuries, the individuality of a language came to reflect the spirit of a nation:

Over the transformations of a Language the genius of a nation unconsciously presides - the issues of Words represent issues in National thought. And in the vernal seasons of a nation's life the formative energy puts forth verbal growths opulent as flowers in spring (quoted in Warren, 28).

According to Warren, this passage represents "American English as an unconscious and necessary expression of "national thought"' (28-29). As a nation evolves, people invent new words and use old ones in different ways to express emerging ideas and sentiments. Through this process, a nation's language is charged with the energies of the day. Language indirectly derives a sense of personality from the nation.

Whitman compares words to "flowers in spring." This analogy conveys a double sense of words as things and as products of a particular place and time. Just as the roots of a flower are nourished by the earth, words are nourished by the nation. Whitman carefully avoids suggesting 
that language conveys or contains spirit. Flowers spring from the earth through a variety of factors that operate in indirect and unseen ways, suggesting that the processes through which a word acquires meaning are also mysterious and multifarious. This is not an image of transmission or embodiment. Words do not represent or refer to national spirit any more than a flower represents or refers to the earth. Instead, word and nation carry on a kind of symbiotic relationship: they feed off and influence one another, but ultimately remain separate. Finally, words and flowers are things, and just as the beauty of flowers consists of a distinct pattern of shapes and colours, so the beauty of words consists of a pattern of meanings, qualities, and associations.

For Whitman, using words as things is only an ideal, and although he may have aspired to it he may or may not have considered himself a "perfect user of words." This implies that in the vast majority of cases words are used as signs, and that it is very difficult to use a word as a thing. If so, it follows that when words are not used as things, the general sense of personality diminishes. When words are employed as purely abstract signifiers, people tend not to register the peculiar flavours they suggest, the evocative coordination of meanings and associations they constitute, passing them over as mere designators of conceptual significance. So when Whitman refers to the exactitude or identity of words, he is not saying each word only means one thing or that words are purely autonomous entities. He is trying to get at the idea that each word comprises a delicate architecture of significance and quality. In order to indicate a particular meaning, a word must specialize, exchanging diversity for specificity, compromising the character of the whole. 
Whitman's notion of words as things sheds new light on several passages in which he refers obscurely to things as words. Warren points to a couple of lines from Whitman's "Song of the Rolling Earth"7: "Earth, round, rolling, compact—suns, moons, animals—all these are words, / Watery, vegetable, sauroid advances - beings, premonitions, lispings of the future- these are vast words." ${ }^{18}$ Warren interprets this passage as a gesture towards an ancient organic language the great poet is capable of recovering:

It is as if the "vast words" of prehistoric "sauroid advances" formed the origins of human language... the problem with this double leap is, of course, that the poet cannot escape the confines of metaphor itself. There is no direct, unmediated relation between words and things, since language is itself the mediator. Whitman attempts to evade the mediated influence of language by proclaiming the things of the earth to be the words of a cosmic language (37).

I do not think Whitman is affirming the possibility of any "direct unmediated relation between words and things." When Whitman refers to objects and living creatures as "words," I think he is referring to the ineffable aura or mystical identity attached to each and every object and living creature. A passage from Emerson might help clarify what Whitman is getting at: "Over everything stands its daemon, or soul, and, as the form of the thing is reflected by the eye, so the soul of the thing is reflected by a melody" (Emerson, 305). In this passage from "The Poet," Emerson describes the peculiar character of a thing as its "daemon" or "soul." In comparing this soul to "music," Emerson suggests that it can be conveyed through an intangible, indistinct

\footnotetext{
${ }^{7}$ This poem has also appeared under the titles "Song of the Sayers of the Earth" and "Carol of Words" in other editions.

8 These lines do not appear after 1871 .
} 
feeling, very much like those evoked by melodies. If so, Emerson's "soul" starts to sound a lot like the sense of personality Whitman attributes to words. Therefore, the "word" could easily be Whitman's term for the distinct affective signature a thing inscribes upon the mind. So there is no need to suppose that Whitman posited a direct embodiment of things in words.

The musical soul is a very important concept in transcendentalism. It features prominently throughout the writings of Emerson, Whitman, and Thoreau. In the following quotation from Walden, the soul of a place or thing is an ineffable spiritual quality the poet captures in verse and takes away:

I have frequently seen a poet withdraw, having enjoyed the most valuable part of a farm, while the crusty farmer supposed that he had got a few wild apples only. Why, the owner does not know it for many years when a poet has put his farm in rhyme, the most admirable kind of invisible fence, has fairly impounded it, milked it, skimmed it, and got all the cream, and left the farmer only the skimmed milk (107).

While the pragmatic farmer supposes the poet foolish for having taken only "a few crusty apples," the poet "milks" the farm for the "cream" of the crop, the intangible ambience which, for Thoreau, is the most valuable part of a place, though so subtle it escapes the farmer's overly practical estimate. As in Emerson's quotation from "The Poet," the character of a place is described as an intangible quality most people do not notice. But the sensitive and discerning mind is capable not only of apprehending it, but also of capturing it in poetry.

This quotation from Thoreau shares many features with a passage that occurs right at the start of Emerson's essay Nature. Emerson begins by defining what exactly nature means to him: 
When we speak of nature in this manner, we have a distinct but most poetical sense in the mind. We mean the integrity of impression made by manifold natural objects... The charming landscape which I saw this morning, is indubitably made up of some twenty or thirty farms. Miller owns this field, Locke that, and Manning the woodland beyond. But none of them owns the landscape. There is a property in the horizon which no man has but he whose eye can integrate all the parts, that is, the poet (5).

Thoreau, it seems, has echoed Emerson in several respects. Emerson too uses the farm to distinguish between land and landscape - nature as it is used and owned for practical purposes, and nature as an embodiment of intangible impressions, what Whitman most commonly refers to as spirit. As in Thoreau, only the poet can fully apprehend these impressions and weave them together in the form of poetry.

For Emerson, just as words stand for ideas, so the natural world suggests spiritual correspondences: "It is not words only that are emblematic; it is things which are emblematic. Every natural fact is a symbol of some spiritual fact. Every appearance in nature corresponds to some state of the mind, and that state of the mind can only be described by presenting that natural appearance as its picture" (14). Things are like words in that they activate spiritual affinities within the perceiver. Whitman does seem to follow Emerson in this regard. He too believes that each and every thing exudes a mystical presence just as words convey a distinct sense of character. However, it is important to point out a number of differences. First, as Irwin observes (12), Emerson seems to follow the metaphysical linguists to some extent in that he believes language has gradually receded from the world into its present arbitrariness: "As we go 
back in history, language becomes more picturesque, until its infancy, when it is all poetry; or all spiritual facts are represented by natural symbols" (15). Emerson associates this process with decay, describing the present state of language as a "rotten diction" that "wise men" redeem by returning it to an earlier state connecting "words again to visible things" (16). On the other hand, as I have already shown, it might be misleading to include Whitman in this tradition, because he believed that words grow richer over time. Furthermore, there is little evidence that Emerson conceived of words holistically, at least not to the same degree as Whitman. Emerson appears to have remained true to a more conventional, referential conception of language. Where Emerson claims that words are "signs of natural facts" (13), Whitman would probably argue that words are natural facts in and of themselves. It is not likely that Whitman derived from Emerson his philosophy of words as things. Emerson does, however, provide a likely source for Whitman's conception of things as words.

Whatever these object-words are, they are shrouded in a sense of mystery that occludes boundaries of signification. Over the course of the two lines from "Song of the Rolling Earth" quoted above, Whitman's imagery descends, grows steadily darker and more obscure. The first line begins with the warm, familiar entities of earth and animals, coupled with the light and elevation of the sun and moon: "these are words." The second line moves from things to qualities of things, "watery, vegetal," creating a sense of dark, low, indistinct form to which "sauroid advances" lends the grand, slow, primordial mystery of the past. From this point on, form is lost altogether. "Premonitions" are intimated through indefinite "lispings of the future." The bright, solid forms of the sun and moon have dissolved into an occult haze of vague mutterings. Whitman echoes the first line's "these are words" with "these are vast words," as if 
the dark, vague terms of the second line are somehow more expansive. This suggests that the more meaningful a word, the less distinct. This is in keeping with Whitman's theory of words. If in order to signify one concept directly a word must compromise its own diversity of import, words are richer when they mean many things at once. Therefore, words are most evocative when least definite.

It might seem odd that the second line groups solid, physical beings along with vague prophetic utterances. However, Whitman, like Emerson, believed that everything exudes a quality peculiar to itself, and that this quality defines intrinsic character like a word. Therefore, Whitman might be trying to say that these affective signatures are accessible only through the subtlest engagement of the intuition, like premonitions. If so, it is very plausible that Whitman did not believe words are somehow organically tied to their referents, but the very opposite. The soul or essence of a thing is so vague that trying to pin it down in words is like trying to catch smoke in a net.

If Whitman is read not as trying to reclaim some mystical union of sign and thing, but as taking into account the prismatic whole of meaning every word contains, it becomes much easier to reconcile his language philosophy with his theory of "indirection." Indirection is the idea that some things are too nebulous for engaged representation, and therefore must be evoked through suggestions or hints. In "Slang in America," Whitman writes:

...I wish you to realize well that our boasted knowledge, precious and manifold as it is, sinks into niches and corners, before the infinite knowledge of the unknown. Of the real world of materials, what, after all, are these specks we call knowledge? - Of the spiritual world I announce to you this — much gibberish will 
always be offered and for a season obeyed...but to make a statement eludes usBy curious indirections only can there be any statement of the spiritual worldand they will all be foolish—Have you noticed the [worm] on a twig reaching out in the immense vacancy time and again, trying point after point? Not more helplessly does the tongue or the pen of man, essay out in the spiritual spheres, to state them. In the nature of things nothing less than the special world itself can know itself-(Workshop, 40).

In this quotation, Whitman imagines the world as a vast sublime that resists all our efforts to understand it. Every material object contains immense stores of information of which the sum of human knowledge amounts to no more than tiny "specks" vastly outweighed by the incomprehensible. By implication, the spiritual world, the intuitive perceptual mode through which the spiritual essence of each thing is accessible, is even more elusive. We can only engage these impressions through "curious indirections," and even then our best efforts are futile as a worm prodding the space off the edge of a twig.

This raises the question of what exactly these "curious indirections" are, and how they work. Howard J. Waskow provides an interesting interpretation of how exactly a poet would go about accessing the spiritual world through indirection:

The reader will be approached by "abstract addresses" no more than will the spiritual world, nor will he have to struggle for meaning... A poem embodying this theory would... have as its focus a list of things: the poet would concentrate on the teeming life of the universe, his subject requiring no pointing to hidden meanings because meanings are in the things, and will be spontaneously sensed 
by the reader. Such a poem, that is, would be wholly made of one of Whitman's catalogues—a poem like "Spontaneous Me," whose title indicates that it is indeed the expression of an extreme organicist (64).

Indirection, according to this reading, makes no use of "abstract addresses" to the reader or nature. That is to say, indirection does not describe, imitate, or refer to the spiritual world. There is no hidden meaning to be extracted from a deceptive surface. Instead, the text consists of a sequence of things and words that simply are in and of themselves and, in the bare fact of their existence, evince plainly their distinctive qualities. For this reason, the indirect mode of representation presents considerable challenges to any critical apparatus that approaches the text according to the traditional depth/surface dichotomy. That said, I find the idea that a truly indirect poem would consist of a single long catalogue limiting. As I will show later on, there are many devices available that Whitman can use while still remaining true to his indirect method. Story, rhythm, the music of language, and gesture all can be used to create or evoke peculiar impressions without referring to any particular thing.

Whitman's theory of indirection might explain why "Song of Myself" makes so little use of figurative devices. V. K. Chari attributes Whitman's plain descriptive style to an underlying commitment to presenting things simply as they are: "Whitman regarded the physical thing as intrinsically interesting and sought to capture it in direct, precise description... Whitman achieved condensation, concreteness, and clarity of visual focus" (177). Nature is so vibrant in itself that using it as a symbolic vehicle for an abstract vision would be irreverent. Instead, according to Chari, Whitman prefers to let nature speak for itself through symbolic extensions immediately apparent at face value. Whitman accomplishes this through "condensation, 
concreteness, and clarity of visual focus." Chari observes that Whitman's style encroaches very little on the natural evocativeness of his subject matter. Even when Whitman does use symbols, he often uses them in such a way that meaning is not definite or even obtainable, eliciting a tremendous number of equally valid interpretations. Chari provides the symbol of the grass as a good example:

In section 6 the poet reads into the blade of grass a variety of significances in an explicit and arbitrary way: now it is 'the flag of my disposition', now 'the handkerchief of the lord', or a 'hieroglyphic'. Not only does this multiplicity of meanings result in a dispersion of the power of the image, but the meanings, too, seem superimposed on the image instead of arising from natural association or from a specially created context. (181)

A child asks Whitman "what is grass?" And Whitman does not know. He then proceeds to interpret grass as a symbol, uncovering so many analogies that the symbol collapses under the weight of its own significance. Grass could be taken to mean pretty much anything, and therefore cannot be said to mean any one thing at all. Whitman uses grass as a symbol, but he uses it "tenderly" (7.13), implying that he will not reduce it to a stale and limited sign, but will respect it for its full vibrant potential as a living thing.

To Nathanson, this passage seems oddly dark because for him, the speaker is troubled by the incomprehensibility of nature: "The darkness and wonder discernible here are provoked not only by the death the poet believes he reads in this 'uniform hieroglyph,' but also by the still elusive meaning of such mortality, the difficult legibility of the natural text” (214). However, any darkness Nathanson sees in the passage is cast by the shadow of his own portrait of Whitman. 
Nathanson sees Whitman agonizingly rifling through nature in search of some ultimate knowledge hidden in reality, when in fact it is the reverse. The "grass" passage as a whole actually celebrates the enigma of nature. Although it is true that Whitman associates grass with death, he imagines it as "the beautiful uncut hair of graves." This image of death constantly sprouting into new life is more likely an optimistic assertion of the eternal renewal of existence, a notion expressed more directly just 16 lines down: "the smallest sprout shows that there is really no death" (6.28). Also, if Whitman's general program really were to recover a lost organic language, why would he make the figurehead of his poetry this enigmatic symbol, unreadable in its remarkable range of analogies and associations? Instead, the symbol of the grass seems to suggest that any number of meanings can be attached to any object, and that the essence of each thing is irreducible and therefore cannot be transposed into language. In effect, the only meaning the grass can definitely be said to have is the polysemous diversity of nature.

The triumph of the spiritual diversity of objects over the specialized reference of signs is a common theme in Song of Myself. Take, for example, "logic and sermons never convince, / The damp of the night drives deeper into my soul" (30). Logic and sermons are both modes through which people try to understand and control the world. Logic allows us to grasp and manipulate things conceptually, while sermons teach us ways to improve our lives. Both express ideas in a clear, linear fashion. Their scope is keen, but narrow. Meanwhile, the "damp of the night" is not limited by specificity of reference, gleaning a more robust experiential harvest.

The strategy of indirection, therefore, is to simply bring a thing to mind without attaching to it any specific idea or value, so that it is free to evoke a multiplicity of thoughts and feelings. By treating words as objects, Whitman extends this power to language. The poet, then, is not a 
mystic translator who renders legible the secret meanings of the earth, but a sensitive and meticulous editor who arranges a series of complementary phenomena that play off one another in new and interesting ways.

In this way, a good poem, like every object and every word, can be said to have a "soul" or a unique "essence" of its own. And for Whitman, this soul or essence was the most important poetic element:

At its best, poetic lore is like what may be heard of conversation in the dusk, from speakers far or hid, of which we get only a few broken murmurs. What is not gather'd is far more - perhaps the main thing. Grandest poetic passages are only to be taken at free removes, as we sometimes look for stars at night, not by gazing directly toward them, but off one side (Complete Prose Works, "Specimen Days," “After Trying a Certain Book”).

Here, Whitman conceives of poetry not as a purveyor of truth, wisdom, or moral value. Instead, just as a conversation heard from a distance resolves into no distinct ideas or expressions, but conveys only a vague sense of atmosphere and presence, so the best of poetic lore is not what it might tell or teach, but the musical mood it creates. And just as a star in the night sky can only be seen on the periphery of vision, so this musical mood cannot be defined, explained, or represented. It must be left unsaid, a hint or insinuation rather than a direct articulation.

The indirect poem is not meant to educate, define, or describe. It is simply meant to exist in the world, as plain and unassuming as a rock or a tree. It does not try to embroider or refine, but only adds to the stores of nature, another natural object itself. As Gay Wilson Allen puts it, "Art is also a product of nature and cosmic processes and grows or develops like an 
organism" (293). Just as an organism grows and changes, incorporating new substances and discarding old ones over the course of a lifetime, while also existing in the world as a thing in itself, so the indirect poem grows out of nature, at once composite and whole. Whitman repeatedly compares his poems to features of the landscape. In the introduction to the London edition of Leaves of Grass, he writes,

I do not purpose to school man in virtues, nor prove anything to the intellect, nor play on the piano, nor rhyme, nor sing amours or romances, nor the epics of signal deeds ... In short, the book will not serve as books serve. But maybe as the rude air, the salt sea, the fire, the woods, and the rocky ground-sharp, full of danger, full of contradictions and offence (130).

The book will not "serve as books serve," because most books inform or persuade. Whitman's poems, however, are to simply be and be read. In this regard, a poem is no different from "the rude air, the salt sea, the fire, the woods," or anything else that exists in the world.

This brings new meaning to Whitman's famous declaration that "The words of my book [are] nothing, the drift of it everything" (Shut Not Your Doors, 4). It does not matter so much what the poem might tell or say. The most important thing is the "drift," the rhythmic development of the whole. Just as the "personality" of a word cannot be grasped by isolating particular meanings, so the drift of a poem cannot be extracted by dissecting specific passages, but is apparent only in its prismatic totality.

Bauerlein sees Whitman as trying to wrestle the inchoate substance of the self into the rigid form of language. But if Whitman celebrates the vague, musical drift over the representational function of words, this poses an issue for Bauerlein's interpretation. Bauerlein 
tries to explain this problem away, claiming that when Whitman celebrates drift over meaning, he "entreats us to ignore the fact" ("Whitman's Language of the Self," 146) that he uses words at all. However, it is equally possible that Whitman simply might not be trying to represent himself as directly as Bauerlein seems to think. In fact, Whitman's theory of language precludes the possibility of clear, unambiguous representation. If each word does not refer to a specific idea or value, but a plurality of ideas and values, then at its best the poem could only present Whitman drastically out of focus. Whitman's language philosophy and his theory of indirection are incompatible with the representational paradigm Bauerlein attributes to him.

At this point, Whitman's theory of indirection might provide the key to the problem of how Whitman can promise to "sing and celebrate" himself while denying himself access through language. Indirection provides an alternative approach to representation, one that is not clearly representational at all. It allows Whitman to evoke a sense of personality through the overall drift of his poem while claiming to remain inviolate of language and its distortions. So when Whitman proclaims Leaves of Grass an expression of personality, he means that the drift of the poem evokes an effervescent fringe of his distinctive character, as a tuning fork can pick up the vibrations of just the right tone from anywhere in the room.

I have argued that Whitman did not consider "Song of Myself" an unmediated representation of himself. Instead, he sought to suggest some peculiar quality of his inner character through indirection. In order for my argument to progress any further, Whitman's concept of character will have to be explored in depth. In this section, I hope to establish three important points. First, character for Whitman is a latent and ineffable spiritual energy. Second, 
character cannot be captured in any immediate representation, but can only be suggested through indirection. Third, among the indirect means available to Whitman as a poet are the music of language, the overall atmosphere or drift of the poem, words as things, and gesture.

The concept of character is best illuminated within the context of Whitman's writings on some of the major figures of the period. Whitman was very interested in the idea of charisma. He was captivated by great statesmen and orators. Father Taylor, the Quaker Elias Hicks, and President Abraham Lincoln all represented a sort of ideal for Whitman. Whitman's writings on these three figures contain traces of a private discourse on charisma, a discourse that, as I will show, stems directly from his ideas about unseen spiritual presences. In Whitman's portraits of Taylor, Hicks, and Lincoln, charisma is a mystical force each great man transmits not through what he says, but how he says it: "the mere words (which usually play such a big part) seem'd altogether to disappear, and the live feeling advanced upon you and seized you with a power before unknown" (Complete Poetry and Prose, 1144). The "mere words," the arbitrary designators of thought, melt away, superseded by a "live feeling" that constitutes the real value of the performance. This live feeling is not communicated through the conceptual content of the speech. It is not something words can express. Instead, it results from an array of effects produced over the course of the performance at large. According to Alan Ackerman, Whitman's contemporaries used the terms electricity and influence to describe this live feeling: "the melding of presence and language, the aura that surrounds both the speaker and the audience and that defies the reifying tendency of the written word, was referred to by Whitman and his contemporaries by a variety of terms but most commonly as "electricity" or "influence" (51). In 
describing charisma as an "aura" that "defies the... written word," Ackerman comes very close to echoing Whitman's description of spiritual essences.

Ackerman goes on to show that electricity or influence, like spiritual essence, can only be conveyed indirectly:

Influence is achieved indirectly, for it involves a working out of psychological and emotional motivations that affect an audience through a process of empathy... Indirect expression, an elliptical mode, is the only way, in Whitman's view, of arousing sympathy... This form of communication expresses the private self through the public, revealing the "within" where character is concealed (66).

This magnetic charisma issues from an unseen and unknown source. It is intensely private and impossible to understand or to explain. It is made available to other people only through a strange and subtle sympathy aroused by the peculiar charm of a speaker's presence or style of address. Like the drift of Whitman's poetry, it is indivisible to any one component, but is conveyed only through the overall character of the whole.

Two brief portraits of major figures who exemplified Whitman's idea of charisma will help clarify the concept of influence. Glenn Cummings provides a useful overview of Whitman's dealings with the Quaker preacher Elias Hicks. According to Cummings, Whitman attended his first Hicks sermon at the age of ten (73), an experience he recounted almost sixty years later in an essay. Whitman describes the profound effect the Quaker had upon him. He remembers being most captivated not by what Hicks said, but by "that unnameable... something [that] emanated from $[$ Hicks $] \ldots$ to the hearts of his audience...-a sympathetic germ, probably rapport, which no book, no rule... has ever given, intuition" (73). Hicks transmitted an indescribable magnetic 
force that thrilled the audience through "a sympathetic germ" that defied logical categories and therefore cannot be taught or explained by any book or rule. It is easy to see how this sympathetic germ sounds a lot like the spiritual essence of a person, place, or thing. Whitman uses very similar language to describe his impression of Lincoln. Lincoln too contains an unspeakable something conveyed by unseen and mysterious forces, so subtle that no artist or photographer has so far been able to capture it: "None of the artists or pictures has caught the deep, though subtle and indirect expression of this man's face. There is something else there" (Complete Prose Works, "Notes (Such as They Are) Founded on Elias Hicks"). Joel Porte relates this fine intuitive apprehension to Whitman's theory of indirect expression:

The key here is Whitman's use of the phrase 'indirect expression' to describe what he sees in Lincoln's face, for it echoes a passage in the 1855 preface in which Whitman announces that 'the expression of the American poet is to be transcendent and new. It is to be indirect and not direct or descriptive or epic.' Expression here must be taken in a double sense, not simply alluding to what the paradigmatic poet, Whitman himself, says, but to what his body expresses (as in the frontispiece): the innerness of being, the essential privacy without which a public figure is simply a hollow shell. The expression of each of these men betokens not only a capacity for personal engagement but also a fund of human meaning not yet articulated, layers of the self still to be uncovered and disclosed (234).

Whitman's theory of influence is intimately related to his poetics. Just as Lincoln's secret sense of personality is suggested not through the things he says or does, but through the most minute 
details of his behaviour, so the definitive American poem must evoke not through any engaged representation or expression, but only through the atmospheric drift of the whole. If personality can be represented only through indirection, and if Whitman's goal is to express his own personality, it is very possible that Whitman believed that he too had an unspeakable something that could be evoked only through the drift of his poems.

C. Carroll Hollis points out that "in trying to write about the platform success of Elias Hicks and Father Taylor [Whitman] unintentionally echoes the transcendental aesthetic" (7). If so, the influence of transcendentalism should probably be addressed. Emerson too is interested in the idea of character, and for him as well it is an unseen, ineffable force hinted by inconspicuous qualities of voice and movement. In The Transcendentalist, Emerson describes the archetypal transcendentalist as a reserved and often misunderstood class. The transcendentalist is solitary, and for that reason often considered ornery and aloof. However, Emerson attempts to redeem the transcendentalist, claiming that this special breed is only solitary out of an intense desire to be loved and a great respect for life and humanity: "these persons are not by nature melancholy, sour, and unsocial... but joyous, susceptible, affectionate; they have even more than others the wish to be loved" (87-88). The transcendentalist is more sensitive to the power of charisma, to the point where the influence of an original and potent character ranks among the most intense and uplifting pleasures life has to offer. It is out of respect for the intimate communion over which a unique and penetrating character presides that they disdain the mundanity and conventionality of every day interactions: "to behold in another the expression of a love so high that it assures itself _... these are degrees on the scale of human happiness to which they have 
ascended; and it is a fidelity to this sentiment which has made common association distasteful to them" (88).

Implicit in this portrait is the sense that it takes one to know one: a distinct and powerful character is hidden, private, and strange, discernible only by the extremely perceptive. As such, it is not something that can be explained or written down. It is not a product of articulation. It is transmitted through silent movements and delicate hints of behaviour. According to Emerson, the transcendentalist seems to say, "If you do not need to hear my thought, because you can read it in my face and behavior, then I will tell it you from sunrise to sunset. If you cannot divine it, you would not understand what I say. I will not molest myself for you. I do not wish to be profaned" (88). If people are not perceptive enough to divine the secret character of the transcendentalist, they have not yet entered the same orbit of experience, and as such would not understand what he or she has to say in any case. Character is an unconscious sense of being that is intimated by minute and spontaneous behaviours. Emerson articulates this most directly in "Spiritual Laws": "Human character evermore publishes itself. The most fugitive deed and word, the mere air of doing a thing, the intimated purpose, expresses character. If you act, you show character; if you sit still, if you sleep, you show it" (184). Character is evinced in everything a person does, even sleep.

Therefore, silence is the most effective means of communication between like minds. In “Circles,” Emerson states this rule quite clearly: "Good as is discourse, silence is better, and shames it. The length of the discourse indicates the distance of thought betwixt the speaker and the hearer. If they were at a perfect understanding in any part, no words would be necessary thereon. If at one in all parts, no words would be suffered" (257). Because character only reveals 
itself through non-verbal cues, through silent presence and behaviour, speech ultimately alienates people from one another. Speech is the measure of separation. The more two people have to say, they less they are in accord.

Emerson and Whitman conceptualize character very similarly. For both, character is ineffable. It is not a product of what is said, but how. In fact, Emerson claims that character is better expressed in silence, suggesting that detailed expression molests or profanes inner character in some way. Whitman echoes this idea when he declares that language would divide him from himself: "I refuse putting from me what I really am" (25.17). Just as the spiritual realm cannot be accessed through language, so the character of a person is corrupted or distorted through engaged expression.

Instead, character must be "read," as Emerson puts it, through the living tissue of being. Emerson alludes to the legend of the "eastern magian" who was sent to "test the merits of Zertusht or Zoroaster" and immediately recognized divinity in the way the sage walked: "This form and this gait cannot lie, and nothing but truth can proceed from them" (337). Whitman echoes this exact passage in "Song of Myself": "my gait is no fault-finder's or rejecter's gait" (22.19). In one of his notebook entries, Whitman states explicitly that character is impressed visibly on the outer form of a "perfect man": "The expression of a perfect made man appears not only in his face — but in his limbs — the motion of his hands and arms and all his joints - his walk — the carriage of his neck — and the fleck of his waist and hips" (Workshop, 62). Whitman describes a walking man as poetry itself: "To see him walk conveys the impression of hearing a beautiful poem" (62). Just as presence and movement openly display the character of the perfect man, so poetry self-evidently evinces the character of the author. There is a passage in 
"Inscriptions" where Whitman compares his poems to a quick glance at his face caught in passing down a road: "I am a man who, sauntering along without fully stopping, turns a casual look upon you and then averts his face, / Leaving it to you to prove and define it" (13). If character is best conveyed through the self-evidence of pure being, this silent glance is an evocative indication of Whitman's personality. Whitman's poems are meant to reveal through concealment, to suggest his character only through the bare fact of existence.

In Experience, Emerson writes, "the definition of spiritual should be that which is its own evidence" (311). This line comes in the middle of a discussion of temperament, which Emerson defines as "a certain uniform tune which the revolving barrel of the music-box must play." Like the spiritual essence of a thing, temperament is described in musical terms. Emerson complains that the scientists of his day cannot quite understand temperament. He denounces physicians and phrenologists as "theoretic kidnappers" who "read the inventory" of a man's "fortune and character" using the "cheap signboards" of the "color of his beard or the slope of his occiput" (311). There is something irreverent about searching for temperament or spirit as if it were a formula that could be determined by a person's measurements. Spirit is not a theory that can be proven, or an unknown that can be calculated. For Emerson, it is apparent to the discerning viewer through a mysterious quality of perception that conforms to no system of logic or reason. We know it is there only because we know it is there.

Whitman seems to share this view when he proclaims that "all truths await in all things / They neither hasten their own delivery nor resist it, / They do not need the obstetric forceps of the surgeon" (30.1-30). All truths are immediately available to the viewer. They do not yield to analysis, but hide in plain sight, ready to awaken at the touch of a sensitive, clear, and healthy 
soul. Whitman's own spirit is likewise self-evident: "I carry the plenum of proof and every thing else in my face" (25.21). Whitman's character cannot be extracted by any systematic or scientific apparatus. It is plainly visible for all to see, as long as you are perceptive enough to see it.

At this point, it is clear that character is essentially a spiritual phenomenon. And it is by virtue of this spiritual dimension that character interpenetrates all things. For Emerson as well as for Whitman, all spiritual impulses stem from an overarching transcendent principle. Every individual is ultimately an outpost of the Over-soul. And character is the medium through which the individual accesses and expresses the transcendent sublime. For this reason, Emerson's conception of the Over-soul is inextricably linked to character:

that Unity, that Over-soul, within which every man's particular being is contained and made one with all other; that common heart, of which all sincere conversation is the worship, to which all right action is submission; that overpowering reality which confutes our tricks and talents, and constrains every one to pass for what he is, and to speak from his character, and not from his tongue (237).

When we speak from "character" instead of from our habitual conditioned perspective, we tap into this infinite fund of inspiration. As such, character might be interpreted as the conduit of the Over-soul. In fact, Emerson often uses the two terms almost interchangeably, as in the following quotation, also from "The Over-Soul": "Character teaches over our head. The infallible index of true progress is found in the tone the man takes... If he have found his centre, the Deity will shine through him" (245-46). If a man commits himself to the sway of the Over-soul, it will manifest involuntarily through his "tone," the ineffable inkling of personality betokened through subtle inflections of behaviour. 
Allen shows how a concept very similar to the Over-soul features prominently throughout Whitman's poetry. He cites "Crossing Brooklyn Ferry," in which Whitman makes reference to a kind of spiritual "float" from which all souls are apportioned to specific bodies (262-264): "I too had been struck from the float forever held in solution, / I too had receiv'd identity by my body" (6.6-7). Allen interprets this "float" as a synonym for "Emerson's Over-soul" (264). He goes on to explain that "at 'birth' each object in nature becomes individualized momentarily... and represents some portion of the soul-stuff which pervades the universe" (264). Friedman arrives at a similar interpretation: "when dissolved in the float of spirit, man is indistinguishable as spirit from the rest of the float, like a particle in any uniform solution. In 'Crossing Brooklyn Ferry' man achieves distinction and identity only through his body, the symbol of his ties to the real world" (454). All souls come from the same cosmic unity, assigned to a specific body and identity. But the soul never falls out of touch with the cosmic sublime. Every soul blends into the common substance of the Over-soul.

Whitman follows Emerson as well in conceiving of character as the conduit of the Oversoul. In November Boughs, Whitman writes, "There is something greater... than all the science and poems of the world above all else... [It is] proved by its practical outcropping in life... the intuitive blending of divine love and faith in a human emotional character" (Complete Prose, "Notes (Such As They Are) On Elias Hicks"). The very fact that Whitman avoids naming this "something greater" suggests that he is talking about the Over-soul. The Over-soul in Emerson is too sublime for words: "Of this pure nature every man is at some time sensible. Language cannot paint it with his colors. It is too subtile. It is undefinable, unmeasurable, but we know that it pervades and contains us. We know that all spiritual being is in man" (238). Furthermore, it is 
great "above all else," an ultimate reality beyond all things. Finally, as in Emerson, the Over-soul never exposes itself to plain sight, but always through the valence of "a human emotional character." Character, therefore, is the means by which the Over-soul manifests through the individual.

Whitman's poetics become increasingly clear. The world is ripe with spiritual essences that can only be accessed through indirection. The spiritual essence of a person is his or her character or magnetism. This ineffable character is conveyed through non-linguistic behavioural cues. This explains why Whitman represents himself only indirectly. It does not, however, adequately explain Whitman's method of doing so. The rhetorical tools available to living, breathing people are not necessarily available to a poet. In life, the orator has voice, tone, and the immediacy of presence at his disposal. Whitman's medium presents an obstacle. Influence cannot be exerted through words, and poetry is nothing but. How can Whitman impart a sense of his character through the bare fact of being if he is not physically there?

John Irwin provides an interesting theory of how Whitman might have overcome these obstacles through gesture and the music of language. Irwin begins by outlining the challenge posed by writing: "a writer of phonetic script whose poetic self consists of that very script, faces, then, a double absence in the use of phonetic signs - the absence both of the live speaking voice and of the referent" (99). Whitman is the object of his own poetry, but he is not really there. He cannot be heard or seen. This sense of absence is only deepened by the arbitrary nature of the linguistic sign. 
Irwin speculates that Whitman circumvents this issue through a very complicated process. This process has two steps. First,

Whitman makes the poetic self the sole referent of the poem. But since the poetic self is, as Whitman makes clear, a visible self—an inscribed, imaged self constituted by the poem's written words - that act makes the poem its own referent. As a result, the absence of the poem's referent is circumvented. In writing, the poet creates a second "poetic self" constituted in and by the text. The poetic self exists only inside the poem. Therefore, when the poem refers to Whitman, it actually refers to itself. As a result, the poet is not really absent, since his presence is constituted by the poem. Second, just as the living, breathing Walt Whitman evinces a vague sense of character through an intangible musical quality, so the poetic self is identified with the musicality of language:

The next step is to identify that universal poem/self with song, with words arranged to produce a rhythm and a melody, an absolute music that transcends the mediation of words; for Whitman's poem/self aspires to that condition of music in which matter and form, inner and outer, blend - a condition in which "presence" is simply that absence of an external referent that we call self-referentiality. What Whitman seeks is the immediacy of music, its power to create immediate conviction (99).

Irwin draws upon Walter Pater to define music as a medium in which, "in its consummate moments, the end is not distinct from the means, the form from the matter, the subject from the expression; they inhere in and completely saturate each other" (39). In music, form and content cannot be distinguished. The song does not refer to anything outside itself. The aesthetic qualities 
of music are immediately apparent at face value. As such, music provides an excellent means for Whitman to create a self-evident poetic identity. After all, Whitman does present the poem as a "song." Since Whitman and Emerson both, as I have shown, often describe character and spirit in musical terms, there is considerable evidence that Whitman could have identified the music of the poem with his persona. In fact, Matthiesson points out that Whitman often describes his poetry as music: "The mode to which he conceived his own poems to belong is made unmistakable by the fact that he did not use the word 'write' in connection with them, but described his activity variously as 'singing,' 'warbling,' 'carolling,' 'trilling,' and "chanting"” (559).

Irwin suggests that gesture is another tool available to the poet in fashioning a poetic self. He argues that Whitman gives his poetic self a visible body that expresses itself through movement:

The kind of immediately convincing presence that Whitman has in mind is not the presence of a speaking voice but of a visible body. "The plenum of proof" is in his face, Whitman says, and the original 1855 edition of Leaves of Grass had a drawing of Walt Whitman as its frontispiece in accordance with the physiognomic/pictographic presence the book was meant to embody. Whitman's poems are intended to be outlines of the body—hieroglyphic gestures (98). Whitman sought to create an "immediately convincing presence" through the physical form of a visible body. When he says the body is "immediately convincing," I suspect Irwin means the body does not try to convince anyone of anything except its own existence. Like music, the body does not refer. 
However, Irwin runs into problems when he describes gesture as "hieroglyphic." Irwin suggests that in both gestures and hieroglyphs meaning is immediately apparent: "considered as pictographs, [hieroglyphs] are constantly employed as a symbol of that ideal condition in which the physical shape of writing is self-evidential" (98). This is true to an extent. Hieroglyphs and gestures are both visual, and they are related to their referents through a connection that is not entirely arbitrary. However, gestures, unlike hieroglyphs, do not necessarily look like what they refer to. Waving, for example, does not look like the concept of "hello." For that reason, the association of hieroglyphs and gestures is somewhat problematic.

Another problem with Irwin's argument is that it is hard to see how a self can be constituted in and by the text. Irwin suggests that the subject matter and the musical language of the poem are identified with a poetic self. If I read Irwin correctly, the poetic self is not just a speaker. It is not simply a figure who moves about the world of the poem, or who narrates from an unspecified location. Instead, the poem is a kind of self, constituted of language as a human being is constituted of nerves, tissues, bones, and organs. Therefore, whenever the poem refers to anything, it is actually referring to one of its own components. In this way, the poem is entirely self-referential. To make his point, Irwin implicitly draws a clear boundary between the poem and the poet, and it is difficult to say whether such a distinction can be made. In any case, it is untrue to Whitman's poetics. Hollis points out that "Song of Myself" is "one of the few poems in the language in which the persona insists he is the poet (61). Whitman identifies himself by name in "Song of Myself." He includes a picture of himself in the first edition of Leaves of Grass, so that readers can associate a face and body with the speaker. He also, as I pointed out earlier, declares in "A Backward Glance" that Leaves of Grass is an expression of his personality. In so 
doing, Whitman insists that the poem refers to the poet. In the introduction to the London edition, Whitman writes that Leaves of Grass "possesses, more than any other known book, the magnetism of living flesh \& blood" (Workshop, 151). The word "magnetism" strongly suggests that Whitman considered the book an extension of his own personality: "There has perhaps never been a book so resolvable into the personality that composed it" (152). Therefore, the poem does, in fact, refer to something outside itself. Whitman did not seek unmediated representation in the way Irwin seems to think. Irwin's observation that Whitman avoided direct acts of reference, however, is very valuable to this analysis, because it remains true to Whitman's theory of indirection.

Irwin helps establish how music and gesture, therefore, are two tools that allow Whitman to exert the power of his influence even in the abstract medium of language. To quickly reconsolidate my argument: influence, as an ineffable spiritual quality, can be conveyed only through indirection. The indirect means available to the orator are voice, presence, and gesture. Of these, only gesture is available to the poet. Poetry, however, comes along with tools of its own. The music of language numbers among the poet's resources. I have also shown how Whitman's language philosophy makes words available to his method of indirection. Therefore, music, gesture, and words are three tools Whitman can use to conduct his influence through poetry. That said, the music of language is very difficult to analyze. It would require a very complex apparatus I do not have space to assemble. For that reason, the remainder of my analysis will focus on Whitman's use of gesture and words in relation to the real Me.

Irwin seems to be using the term gesture in a loose and general way. Some gestures have a completely arbitrary relation to their referents in which meaning is not self-evident at all but 
very much culturally encoded, such as the thumbs-up expression. In order to progress any further this discussion of gesture requires a clarification of terms. David McNeil follows Adam Kendon in classifying gesture into four main types: gesticulations, signs, emblems, and pointing (12). Each category is defined by a different relationship between form and meaning. Form concerns the movement of the gesture. Meaning concerns the thought or feeling the gesture refers to. Emblems operate very similarly to language. They are connected arbitrarily with ideas through cultural encoding. McNeil uses the "OK" sign made with the second finger and thumb as an example. Signs are like emblems, except they are involved in systematic sign languages designed for the deaf. Pointing is self-explanatory.

This leaves gesticulations, "by far the most frequent type of gesture in daily use" (12). Gesticulations lack linguistic properties. They cannot be segmented—broken down into components. For that reason, it is difficult to say where one gesticulation ends and another begins. Patrice Pavis and Biller-Lappin show that it is difficult to identify individual gesticulations, and therefore hard to say which gesticulation means what: to signify is to be able to segment, and... the analysis of the movement has to go through a structuring of body and gesture... As soon as one segments a single gesture into discrete units, one has to justify its segmentation into signifiers, and to indicate why one chooses to indicate those signifiers within certain limits within the gestural flow. However, segmentation by signifier... seems to be quite difficult, since one must resort to meaning to be able to extract a global fragment (syntagm) whereby that fragment will comprise the ensemble of the gestural unit in all its phases, within it (92). 
It is impossible to determine what a gesticulation refers to without isolating specific parts and showing how those parts match up to particular concepts. But it is difficult to break down a gesticulation because it is hard to say where one part ends and another begins. For that reason, gesticulations are not clearly referential.

David McNeil takes it one step further and argues that gesticulations do not refer to specific concepts at all. Instead, they develop out of what McNeil calls "growth points." A growth point is an inchoate mass of thought. A thought does not occur to us broken down and organized in neat conceptual chunks, but as a jumbled mass of concepts and qualities. In order to be put into words, a thought must first be disassembled. Articulation, therefore, consists of putting coherent, imagistic thoughts into segmented form so that they can then be put into words: Thought, unlike speech, does not consist of separate units. When I wish to communicate the thought that today I saw a barefoot boy in a blue short running down the street, I do not see every item separately: the boy, the shirt, its blue color, his running, the absence of shoes. I conceive of all this in one thought, but I put it into separate words (85).

If I interpret McNeil correctly, gesticulations access thought differently than words. Whereas words are analytic and sequential, gesticulations capture meaning in a more intuitive, figurative way. Words break thought down, gesticulations do not. Instead, gesticulations stem out of thought into the outside word: "Gesture, as part of the GP [growth point] is inhabited by the... 'living meaning"' of thought (92).

To summarize, thoughts are not broken down, at least not at first. Gesticulations are likewise not broken down. It is hard to say which parts of a thought the gesticulation refers to 
and which it does not. If signification requires segmentation, gesticulation cannot really be said to signify. Instead, gesture extends from thought as a leaf extends from a stem. It is easy to distinguish the leaf from the stem; it is easy to distinguish between gesture and thought. However, as leaf and stem are part of the same plant, so thought and gesture are part of the same mental configuration. The leaf does not refer to the stem. The leaf extends the substance of the plant into a different form. In the same way, gesticulation extends thought into movement. As McNeil puts it, a gesticulation is “not a 'representation' of meaning, but instead meaning 'inhabits' it" (92). Gesticulation is not arbitrary movement that refers back to meaning, but instead meaning is present within the movement itself. Form and meaning, therefore, are indivisible.

For my purposes, it is necessary only to establish two points: first, when Irwin speaks of gesture, he is probably referring to gesticulation. To avoid confusion, I will continue using the term gesture. Second, gestures cannot be segmented, and therefore cannot clearly be designated as signifiers. Therefore, it is hard to claim that gestures are referential. It might be objected that, to an equal extent, a gesture cannot be separated from mental content. However, as I will show, Whitman often makes a point of dissociating gestures from thoughts and feelings as much as he can, emphasizing the pure visuality of movement. This strongly suggests that Whitman employs gestures not as expressive or representational acts, but as non-referential movements. Therefore, gestures, like music, create indistinct impressions that do not refer to any one thing in particular, and as such are fine and subtle enough to register faint traces of Whitman's ineffable character. Gesture, therefore, serves as an excellent means of indirection. 
According to Ackerman, Whitman conceived of gesture as one of the primary means through which an orator manifests influence. Whitman distinguished between interior and outward gestures, which Ackerman interprets as "a response to texts... which provide comprehensive discussions of outward gesture... The lifting of the head signifies arrogance or pride, and eyes turned down show modesty. Interior gesture, on the other hand, corresponds to the ineffable qualities that go into the making of a character" (67). Outward gestures are overt. Meaning is clear and culturally established. Interior gestures are subtle, unseen effects of voice and presence, a "great feeling in voice and look" (Workshop, 37). Interior gesture is not gesture per se. It is more like a sense of animation implicit in the speaker's force of being:

The amount of all this about interior gesture and a flowing forth of power, simply is: that so much must have been generated, such an exhaustless flood of vitality, tone, sympathy, command, and the undeniable clinch... that a subtle something equivalent to gesture and life plays continuously out of every feature of the face and every limb and joint of the body, whether active or still (37-38).

"A subtle something" echoes the phrase "unspeakable something" that Whitman uses to describe the ineffable character of Abraham Lincoln. Interior gesture might then be read as the spiritual equivalent of outward gesture. Where outward gesture is the physical movement of the body, interior gesture is the invisible movement of the soul, which manifests as an indefinable quality that cannot be placed yet is undeniably there: "Within, the memory, the fancy, the judgment, the passions are all busy; without, every muscle, every nerve is exerted; not a feature, not a limb, but speaks." The speaker's body is pervaded with his own magnetism, infusing the air with the force of his charisma, bringing the audience together in a single thrilling identification that transcends 
individual selves: "Notwithstanding the diversity of minds in such a multitude, by the lightning of eloquence, they are melted into one mass, the whole assembly actuated in one and the same way, become as it were but one man, and have but one voice" (38). The main point I want to stress is that Whitman conceived of the unseen manifestation of character in gestural terms.

Which is not to say that Whitman disregarded outward gesture by any means:

"Animation of limbs hands, arms, neck, shoulders, waist, open breast, \&c.- - the fullest type of live oratory—at times an expanding chest at other times reaching forward, bending figure, raised to its fullest height, bending way over, low down, \&c.” (38). Here, Whitman describes the "fullest type of live oratory" as that which makes robust use of overt and visible gestures. At points, Whitman can even be seen coaching himself into making use of strong, overt movements: "Sweeping movements, electric and broad style of the hands, arms, and all the upper joints. These are to be developed just as much as the voice by practice" (38). Scattered throughout Whitman's lecture notes are stage directions and little notes to himself which suggest that he intended to deliver these lectures someday.

Hollis makes it clear that Whitman certainly wanted to be an orator (1). However, Whitman was probably not very good at public speaking. That said, he did give a few lectures and poetry readings. These performances were not well received (22-23). Perhaps for this reason, Whitman wrote a few anonymous reviews that reflect favourably upon his own lectures. These reviews help make two important points. First, Whitman believed that he had magnetism. Second, gesture is an important conduit of this magnetism.

On September 8, 1871, Whitman presented "After All Not to Create Only" at the opening of the trade exhibition in New York (21). There were very few people in the audience, and there 
was a lot of background noise that made it difficult to hear the reading. But Whitman published an anonymous review in which he describes it as a great success:

His manner was at first sight coldly quiet, but soon you felt a magnetism and felt stirred. His great figure was clothed in gray, with a white vest, no necktie, and his beard was unshorn as ever. His voice is magnificent, and is to be mentioned with Nature's oceans and the music for forests and hills. His gestures are few, but significant. Sometimes he stands with his hands in his pockets; once or twice he walked a few steps to and fro. He did not mind the distant noises and the litter and machinery, but doubtless rather enjoyed them. He was perfectly self-possessed (22).

Whitman attributes to himself the magnetism of influence. This magnetism is subtle and indistinct, conveyed even though his "coldly quiet" demeanor. The primary vehicles of his character are voice and gesture. In comparing his voice to the sea and the music of forests and hills, Whitman emphasizes tone over import. Once again, it is not so important what the speaker says as how he says it. His gestures are "few but important." Whitman describes himself walking to and fro and placing his hands in his pockets. Neither of these gestures clearly means anything. They indicate no single thought or feeling directly. Instead, Whitman seems to think of them as understated manifestations of character.

Whitman wrote another anonymous review in praise of another reading he gave at

\section{Dartmouth:}

He was very easy in his delivery, and evinced an unusual degree of what might be called inward emphasis, but outwardly he shows perfect nonchalance. His vitality 
and electricity are in the voice, which, although not startling and loud is impressive and animating beyond example... The lesson of Whitman's elocution is of value to our speakers and orators, who deeply need these qualities of vocal perfection — outward quiet and interior magnetism, which he possesses so abundantly... Whitman uses few gestures, generally speaks quietly, deliberately, only sometimes rapidly, pauses a good deal, has a way of putting his hands in his breast pockets... in his inherent intellectual animation [he] is probably beyond that of any speaker of the age. (23)

Whitman's rhetoric is strikingly similar here. He stresses the subtlety and plainness of the speaker's performance. Character is conceived as a fund of potential held in reserve that trickles through the finest features of voice and movement. The speaker is impressive but not startling, animating but not loud. Whitman uses the same terminology to describe his own charisma as he did for Lincoln's and Taylor's: "electricity" and "magnetism." And here again we have Whitman putting his hands in his breast pockets, suggesting that he might have identified consciously with this gesture. Finally, Whitman refers to his own "inward emphasis." This phrase sounds a lot like "interior gesture" as outlined earlier. It is likely that inward emphasis refers to the range of subtle effects through which inner character manifests.

At this point, it is clear that Whitman sought to manifest his character in poetry. Since character is too nebulous for engaged representation, it can only be conveyed through indirection. Among the indirect means available to Whitman as a poet are the music of language, words as things, and gesture. However, before I begin examining specific passages, I have to 
establish one more claim: in "Song of Myself," the real Me is the poetic incarnation of Whitman's distinct character.

Rountree points to two passages that provide strong support for this claim. In his Prose Works, Whitman writes, "the idea of my poetry is that there is something behind - something behind" (VII, 107). Rountree reads this to mean that "there is a common life or essence underlying forms" (550). Fundamentally, the idea of Whitman's poetry is that every creature and every thing has some sort of spiritual essence. The poet's job is to somehow access it.

The second quotation occurs in "a fragmentary note on the philosophy behind Leaves of Grass." Whitman writes that "behind all the faculties of the human being there 'stands the real power, the mystical identity, the real I or Me or You"” (550). Behind each thing stands its essence. Behind each person stands his or her "real I." This strongly suggests that when Whitman refers to spiritual essence and the "real I or Me or You," he is talking about the same thing. Furthermore, the real I is described as a "mystical identity." It is a spiritual phenomenon that defines a person, just as a spiritual essence defines a thing. If character, as I have shown previously, is the spiritual essence of a person, it follows that Whitman's real Me is his poetic incarnation of character. This claim will receive further support over the course of my analysis.

In order to avoid confusion, I need to circumvent a possible misunderstanding that concerns Whitman's peculiar presentation of the real Me. Whitman rarely speaks in the voice of the real Me. He almost always refers to it in the third person. This creates the sense that there are two sides to Whitman: the universal I who speaks and the real Me that waits silently off to the side. As Waskow puts it: 
there is not one Whitman, who unifies body and soul and is harmonious with all the world, but two: the 'mystical identity,' the 'real power,' which is beyond particular body and is haughty or loving as the spirit moves it; and the actual identity, conscious of its internal split between body and soul and plagued by the presence of 'seekers and askers' (180).

Whitman sees himself as divided between a spiritual essence — his real Me—and a conscious identity - the speaking I. He speaks from the perspective of the I, frequently encountering the real Me as if it were another person.

Whitman's I is capable of radical empathic identification with other people and things. As Feidelson notes, "the 'I' of Whitman's poems speaks the world that he sees, and sees the world that he speaks, and does this by becoming the reality of his vision and his words" (18). In a similar vein, Friedman argues that "man can perceive an object, Whitman maintained, only by imaginatively identifying himself with it" (451). Perception, in Whitman, is an act of identification. Whitman himself states this clearly when he says, "Is this then a touch? quivering me to a new identity" (28.1). Even a light touch reconfigures Whitman's sense of himself. The viewer becomes what he sees: "I do not ask the wounded person how he feels, I myself become the wounded person" (33.147).

However, critics often point out that in these overwhelming empathic acts there is always something that resists assimilation into the new identity, something that remains behind. I argue that this is the real Me, the core of Whitman's being that resists absorption into the outside world. While the conscious I gets carried away in flights of ecstatic feeling, the real Me anchors Whitman in himself. At one point Whitman loses himself in nature and is brought back down to 
earth by a quick pause to recuperate: "a minute and a drop of me settle my brain" (46). Here, Whitman takes a moment to relax and have a drop of himself that, like a drop of medicine, restores balance to a veering, exultant ego. Nathanson arrives at a similar conclusion:

The protagonist's delight in inhabiting a specific body mingles pleasure in the particular guise assumed with a satisfaction about which he is less forthcoming; as if he still abided somewhere apart from the limiting form in which we glimpse him, the poet seems to remain strangely unapproachable and inviolate (373). I argue that this fragment of Whitman's self that remains apart from the kaleidoscope of Whitman's successive forms is the real Me.

Over the course of my analysis there will be several key sections where the speaker considers the real Me as an object of consciousness. At other moments, the I is taken up in euphoric communion with nature. When this happens, the speaker splits off from the real Me, and the real Me often takes the form of a silent bystander. Throughout "Song of Myself," it is evident that Whitman conceived of himself as two separate entities: one conscious, voluble, and changing, the other silent and immutable.

With this established, I will examine several key passages in which the real Me makes an appearance. My interpretations are meant to support two main premises. First, the real Me represents Whitman's character. Second, because character cannot be captured in language, Whitman approaches it through indirection. Throughout the poem, therefore, the real Me is removed from direct involvement in the outside world. It never speaks and is never clearly defined. For this reason, at times it will be necessary to provide evidence that the figure in 
question is, in fact, the real Me. Aside from a few odd but carefully chosen adjectives, the only insight afforded into the real Me is supplied by gesture. Within the context of Whitman's writings on oratory, it is safe to assume that in these passages Whitman renders the interior gestures of spirit visible to the reader.

The real Me makes its first appearance in section three: "Sure as the most certain sure, plumb in the uprights, well entretied, braced in the beams, / Stout as a horse, affectionate, haughty, electrical, / I and this mystery here we stand" (3.12-14). Whitman enumerates a list of qualities he attributes to himself and a "mystery" that stands at his side. Frederik Schyberg thinks the mystery is that of nature (166). This is possible, but I think it is more likely the real Me. Whitman is describing himself, so it simply makes more sense that the mystery is a part of him. Also, Whitman refers to himself more often than not as two distinct entities. With this in mind, it is not entirely clear which qualities in this short list describe the speaker, and which the real Me. However, it is significant that Whitman describes himself as "electrical." Electricity was, as already shown, a term commonly used for charisma at the time. As such, the word "electrical" indicates an indescribable force of character supplied by the mystery of the real Me.

The real Me makes a more concrete appearance in section four:

Trippers and askers surround me,

People I meet, the effect upon me of my early life or the ward and city I live in, or the nation,

The latest dates, discoveries, inventions, societies, authors old and new, My dinner, dress, associates, looks, compliments, dues, The real or fancied indifference of some man or woman I love, 
The sickness of one of my folks or of myself, or ill-doing or loss or lack of money, or

depressions or exaltations,

Battles, the horrors of fratricidal war, the fever of doubtful news, the fitful events;

These come to me days and nights and go from me again,

But they are not the Me myself. (4.2-9)

Apart from the pulling and hauling stands what I am,

Stands amused, complacent, compassionating, idle, unitary,

Looks down, is erect, or bends an arm on an impalpable certain rest,

Looking with side-curved head curious what will come next,

Both in and out of the game and watching and wondering at it. (4.10-14).

Although Whitman does not tell us directly what the real Me/Me myself is, he does tell us what it is not. He goes through a long list of concerns, dismissing them all under the heading of "trippers and askers." James Miller interprets the "trippers and askers" as people who, "with their doubt and their skepticism and debate about a 'beginning' and an 'end,' are too much involved in the minutiae of daily living and too readily accept inherited beliefs to experience the 'felt' order in the apparent chaos of existence" (9), people who care too much about the little things and lose sight of the big picture. The word "trippers" implies that all these mundane concerns get in the way of the steady operation of individual existence. They are the obstacles, the fretting, the obligations that prevent us from living freely. Miller argues 
that Whitman sees himself as somehow beyond these worldly cares: "the poet, 'both in and out of the game and watching and wondering at it,' portrays himself as withdrawn, withholding comment and judgment—prepared for the imminent union with his soul" (9) of section five. Miller makes no distinction between the speaker and the real Me. Whitman, for Miller, is totally disengaged from every-day concerns.

Miller's reading has two small problems. For one, this short catalogue of section four is not all mundane concerns. Whitman includes serious matters as well: sickness, poverty, war, and disaster, among others. The trippers and askers are not so parochial as Miller seems to think. They are also people who care when their loved ones die, when the country goes to war. And Whitman clearly cares about these things too. If, upon witnessing a slave taken down by dogs and beaten, Whitman is overcome by such a powerful sympathy that he "becomes" the slave (52), it is very likely that he is deeply affected by war and illness as well. Indeed, Whitman explicitly acknowledges that these concerns are somewhat significant to him: "These come to me days and nights and go from me again, / but they are not the Me myself."

This passage only makes sense if the speaker and the Me myself are considered separately. Waskow directly addresses this distinction. He interprets the Me myself as the speaker's ideal self. The speaker is therefore divided because he can never quite measure up to the man he would like to be (162). This reading presents yet another conflicted and anxious Whitman that, as in Bauerlein and Nathanson, is constantly haunted by his shortcomings. According to Waskow, Whitman is 
torn between celebration of his ideal self, the self harmonious with readers and all the world, and acknowledgment of his 'actual self,' the self that must contend with the 'pulling and hauling' of everyday difficulties. The rest of the poem records the speaker's long struggle to modify his attitudes toward these warring selves, thereby to reconcile them and make a whole identity (163).

For Waskow, Whitman would like to be able to stop caring so much, to be unaffected by the concerns and difficulties of daily life. He struggles to transcend a world that constantly oppresses him.

I do not see any evidence that the Me myself is an ideal Whitman yearns to realize. As far as I can see, the Me myself is disengaged, to a great extent, from the outside world. There is no indication throughout the poem that Whitman would like to retreat permanently into a detached and purely observant state of being. In fact, such a radical detachment seems antithetical to the all-embracing attitude of the speaker. Waskow, therefore, contradicts himself somewhat when he describes Whitman's ideal as simultaneously "harmonious with readers and all the world," while also "in and out of the game and watching and wondering at it."

So the Me myself cannot be read as Whitman's ideal self. In fact, the opposite is more plausible: the Me myself is some unassimilable substance of being that prevents the realization of an ideal self. An ideal self, if I read Waskow correctly, is an abstract mental image. People try to make this image real by projecting it upon material existence, identifying with clothing, friends, and achievements, among other things. Identity, therefore, is constructed through attachments with the outside world. But these attachments are 
ultimately imaginary and transient. They come and they go. They are not really us. The self is too complex to be fully absorbed into a conceptual identity. If the Me myself, as Whitman seems to claim, resists all these outward identifications, it more likely represents the raw matter of being. It is too nebulous to be conceptualized. It resists categories. It is mysterious and vague.

A quotation from Thoreau might help clarify what I mean. This quotation occurs in Walden, and shares striking similarities with the passage quoted above:

We are not wholly involved in Nature. I may be either the driftwood in the stream, or Indra in the sky looking down on it. I may be affected by a theatrical exhibition; on the other hand, I may not be affected by an actual event which appears to concern me much more. I only know myself as a human entity; the scene, so to speak, of thoughts and affections; and am sensible of a certain doubleness by which I can stand as remote from myself as from another. However intense my experience, I am conscious of the presence and criticism of a part of me, which, as it were, is not a part of me, but spectator, sharing no experience, but taking note of it, and that is no more I than it is you. When the play, it may be the tragedy, of life is over, the spectator goes his way. It was a kind of fiction, a work of the imagination only, so far as he was concerned (177-178).

All experiences, no matter how intense, do not absorb the self completely. There is always some scrap of mental being that holds back uninvolved, critical, and observant. It is easy to see how this "spectator" strongly resembles the real Me. However, where Thoreau insists that 
this spectator is not him, for Whitman it constitutes the real him. This is a very important distinction to make. For Whitman, identity is constantly changing. Every new experience is, essentially, a new identity. But although experience can be intense, it never truly pervades the self. The Me myself always remains aloof, ultimately unpossessed.

That said, Waskow does help make two important points. First, the I and the Me myself are two separate elements of a single entity. Second, the speaker is susceptible to the “"pulling and hauling' of everyday difficulties" while the Me myself is not. Whitman the speaker is subject to all the trials and tribulations that come and go over the course of a lifetime. He feels emotion, vanity, personal attachments. All these things come to him, affect him for a while and change him to a degree. But the ineffable center of Whitman's self remains untouched.

With Whitman's ideas about character on the table, it makes sense that the Me myself would not be a product of "dinner, dress, associates, looks, compliments, dues.” These concerns are social, overt, and superficial. Character is private, ineffable, and latent. Emerson clearly defines it as such:

This is that which we call Character-a reserved force, which acts directly by presence and without means. It is conceived of as a certain undemonstrable force, a Familiar or Genius, by whose impulses the man is guided, but whose counsels he cannot impart; which is company for him, so that such men are often solitary, or if they chance to be social, do not need society but can entertain themselves very well alone... What others effect by talent or by 
eloquence, this man accomplishes by some magnetism. 'Half his strength he put not forth' (328).

Character acts "without means." It is a hidden fund of spirit implied through mysterious effects of presence and behaviour. It "cannot be demonstrated": it can only be inhibited by any deliberate cultivation of appearance or manner. If the Me myself does, in fact, stand for Whitman's inner character, this explains why it precludes vanity, pride, and personal engagements.

However, as I pointed out earlier, the Me myself also stands apart from serious personal and historical issues. If I am accurate in reading the Me myself as character, Whitman is consistent with other transcendentalists in this regard. Emerson writes that the man of character remains relatively self-possessed, while "the other class... worship events; secure to them a fact, a connection, a certain chain of circumstances, and they will ask no more" (331). By "the other class," Emerson means people who either do not have character or repress it. He implies that the vast majority of men and women inhibit spiritual impulses and rely on exterior social facts as the basis of identity. They "secure to them a fact, a connection, a certain chain of circumstances"- they dwell on successes and tragedies, entrench themselves into a set lifestyle, make and break relationships, and rely on these affiliations to represent themselves. But of course, according to Emerson, none of these external facts really determine who or what a person is. Character exists independently of social standing.

Because character cannot be expressed or described in words, the Me myself says nothing, but expresses itself only through gesture. The Me myself looks down, stands erect, 
bends an arm "on an impalpable certain rest," and tilts its head on one side. None of these gestures can definitely be said to express anything in particular. As literary renderings of interior gesture, they are meant to suggest only a faint trace of Whitman's sense of himself.

In section five, Whitman introduces another mysterious, silent incarnation of poetic character-the soul:

Loafe with me on the grass, loose the stop from your throat, Not words, not music or rhyme I want, not custom or lecture, not even the best, Only the lull I like, the hum of your valved voice.

I mind how once we lay such a transparent summer morning, How you settled your head athwart my hips and gently turn'd over upon me, And parted the shirt from my bosom-bone, and plunged your tongue to my barestript heart,

And reach'd till you felt my beard, and reach'd till you held my feet. (5.3-9).

It is obvious that the soul and the real Me share a number of salient features. They are both impalpable, separate from the body and from the speaker. Neither says anything throughout the poem, but each expresses itself only through non-linguistic behaviour-in this case, a pure rush of sound and a series of ambiguous gestures. Furthermore, Whitman and Emerson both refer to the spiritual essence of a thing as its soul. Finally, Whitman consistently refers to himself as two, without any mention of a third. In "Song of Myself," he declares, "I believe in you my soul / the other I am must not abase itself to you" (5.1). And in one of his notebooks: "I cannot understand the mystery, but I am always conscious of myself as two — as my soul and I: and I reckon it is the 
same with all men and women" (Uncollected Poetry and Prose, 66). Whitman is only conscious of himself as $t w o$. This seems to rule out the possibility of a third. Although it might be possible to read this last quotation as "I cannot understand the mystery of the real Me," that would be a stretch. This quotation comes from a short entry devoted to Whitman's ideas about the soul, in which there is no mention of any additional constituent. The only indication that the real Me might be distinct is that Whitman calls it by a different name. But this could also be a way of mystifying the soul. By referring to the soul by several different names, Whitman frees it from the received Christian conceptualization, allowing him to redefine it from a transcendentalist perspective.

One major critic who insists that the soul and the real Me are different is Harold Bloom. However, his main objection is simply that it is hard to consider Whitman's speaker in the passive role it here assumes: "If we translate soul as 'character' and self as 'personality,' then we would find it difficult to identify so passive a personality with 'Walt Whitman, a kosmos, etc.'... Clearly, there is a division in Whitman between two elements in the self, as well as between self and soul" (257). Although I agree that the soul is associated with Whitman's character, I do not think the self can be translated as "personality." First, it is not clear that the two terms are all that different, and Bloom does not clarify. Whitman uses character and personality interchangeably throughout his writings. Also, I think it is more accurate to read the speaker here as Whitman's conscious identity.

If so, Whitman's theory of identity does not in any way make it unsuitable for the passive role. In fact, as Thomas Byers points out, Whitman often uses sex as an analogy for the intermingling of self and world - "The interaction of self and nature is commonly expressed in a 
diction burning with sexual connotations" (Byers, 38) —and the speaking I usually assumes a passive role. The "is this then a touch?" episode is a good example. Whitman comes into contact with someone or something, and is completely overwhelmed by sensation:

On all sides prurient provokers stiffening my limbs, Straining the udder of my heart for its withheld drip, Behaving licentious toward me, taking no denial, Depriving me of my best as for a purpose, Unbuttoning my clothes, holding me by the bare waist (28.5-9).

Here, Whitman describes the act of perception as a kind of sensory rape in which he is penetrated by stimulation and helpless to resist. Sensation unbuttons his clothes and holds him by the waist, "quivering" him to a "new identity" (28.1). As a direct and immediate result of sensory input, identity is helplessly subject to the whims of the senses. As such, it is not at all inconsistent with the passive role. Bloom's objection does not undermine my argument. There is, again, no reason to read in any distinction between the real Me and the soul.

Section five provides further evidence that the soul and the real Me are poetic incarnations of Whitman's character. Bloom has already suggested as much. Furthermore, several critics have all observed that the soul in this episode appears to represent what R.W.B. Lewis calls Whitman's “creative genius" (107), the inhabiting spiritual force that, under the right conditions, manifests in poetic language and evocative imagery. Allen too argues that Whitman is "conscious of his imaginative faculty as a distinct identity or personality, which he addresses as 'my Soul'" (252). Waskow arrives at a similar interpretation. He argues that when self and soul unite, the resulting lull is a kind of song that stands for the poem itself. To support his argument, 
he points out a number of useful parallels. At the very beginning of the poem, Whitman declares, "I sing myself, and celebrate myself." Almost immediately after, he suggests that the soul is the source of his poetic vision: "I loafe and invite my soul" (1.3). Section five begins in perfect symmetry, with Whitman inviting his soul to "loafe" with him "on the grass" (5.3). And, as Waskow observes, this loafing leads to song: "[Whitman] wants his soul to sing through his mouth a special kind of song: a song without music or rhyme... a song free of didacticism, 'even the best'; a song, in fact, that has no words but simply provides the kind of lulling accompaniment suitable for the story that follows" (163-64). In essence, Waskow argues that episode five is a sort of "Song of Myself" in miniature. Just as "Song of Myself" evokes through indirection instead of abstract reference or allegory, so the lull of the soul is "free of didacticism," containing no direct moral or lesson. Therefore, the soul is Whitman's "poetic muse" (163).

It is, by now, very clear that Whitman considered "Song of Myself" an extension of his character. Here, the soul becomes the inspiration, the guiding force, through which the poem comes to be. This strongly suggests that character and soul, if not one and the same, are at least closely related. If I were to offer a tentative speculation as to what exactly this relation might be, I would say that character is the soul in operation, active and vibrating through the electric pulse of the speaker. If the soul is intrinsically linked to character, this explains why it only expresses itself through undifferentiated sound and gesture. The lull is pure, non-linguistic noise. It refers to nothing. It evokes only auditory qualities. The gestures are also not clearly emblematic. After plunging its tongue into Whitman's heart, the soul reaches up to his beard, and then down to his 
feet. Once again, these might be interior gestures upon which Whitman has bestowed discernible form.

Although I agree with critics that these gestures are sexually suggestive (Miller, 10; Byers, 18), I do not think they are clearly sexual. There is nothing arousing about gripping a beard or some feet, or licking a heart. These gestures are equally suggestive of other things. In fact, Whitman appears to have deliberately selected gestures that are not strictly embedded in any particular significance or cultural association. There are a lot of other bodily movements Whitman could have used that connote sexuality more simply and directly, such as kissing and hugging. Instead, Whitman blurs lines of reference and association, emphasizing the visual form of movement. He selects gestures that speak across a wider range of images and associations, so that it is very difficult to clearly isolate a single determinate referent. Therefore, within the framework of Whitman's philosophy of indirection, these gestures can be read as vague hints of inner character.

Part 11, the "twenty-eight young men" episode, shares striking parallels with section five. A wealthy, upper-middle-class woman watches twenty-eight young men bathing from her window. She is twenty-eight years old, and "all so lonesome," implying that she is so far unmarried, and probably worried that she will soon be too old to marry at all. Cooped up and solitary, the scene outside her window sets the stage for sexual fantasy. She imagines herself bathing with the young men:

Where are you off to, lady? For I see you, You splash in the water there, yet stay stock still in your room. Dancing and laughing along the beach came the twenty ninth bather, 
The rest did not see her, but she saw them and loved them. (11.8-11)

Schyberg complains that this episode comes out of nowhere, relating to nothing else in the poem (99). Schyberg does, however, express a vague intuition that this episode might have an underlying "mystical" theme: "There is no questioning the remarkable force and clarity almost of a mystical sort of episode, supported by the occult numbers (twenty-eight young men and her twenty-eight years) to which Whitman was now and then partial" (99).

Although Schyberg does not develop his intuition any further, I think it might be possible to take his challenge and read this narrative as an analogy for the private and sequestered soul, stimulated by the outside world but never truly capable of merging with it. There is some evidence for this. First, as already mentioned, Whitman often uses sex as an analogy for the spiritual communion of soul and nature. Second, such an interpretation would thematically integrate the otherwise anomalous passage with the rest of the poem. Also, the analogy holds fast: just as the soul is aroused by mysterious affinities with an outside world it can never inhabit, so the woman is aroused by the young men outside her window she can never touch. This unrequited love of the soul for nature is a recurring theme throughout Emerson's essays: “There will be the same gulf between every me and thee as between the original and the picture. The universe is the bride of the soul... Two human beings are like globes, which can touch only at a point, and whilst they remain in contact all other points of the each of the spheres are inert" (322-23). Just as the woman would love to have sex with the young men but cannot, so the desire for absolute absorption in spiritual identification is forever unfulfilled due to the insurmountable rift between self and world. 
Like the real Me, the woman is utterly secluded and does not speak. The reader's only insight into her private thoughts is betrayed by the imaginary acts and gestures through which she plays out her sexual fantasy. The woman starts envisioning her hand passing over the naked bodies of the young bathers: "It descended tremblingly from their temples and ribs" (15). Soon after, her imagination gets more involved:

The young men float on their backs, their white bellies bulge to the sun, they do not ask who seizes fast to them,

They do not know who puffs and declines with pendant and bending arch, They do not know whom they souse with spray (16-19).

In her mind, she "seizes fast" to the men and "puffs and declines with pendant and bending arch." Like those in section five, the "pendant and bending arch" is a desexualized gesture in a sexual context. It can, in fact, be considered a gesture and not an action only because bending does not necessarily serve a sexual end. Once again, Whitman could easily have chosen another bodily movement more directly associated with sexuality. But instead, he chooses the graceful and highly formalized "pendant and bending arch." Here too Whitman promotes visual character over expressive impetus. The gesture evokes a more diverse range of impressions and associations, not all necessarily related to sexuality. Under these circumstances, it might be read as yet another interior gesture transposed onto the page. If the woman represents the real Me, utterly removed from the outside world, this gesture might be said to register, in an indirect and indescribable way, the vague tenor of Whitman's private character.

Whitman's use of language here is also interesting, particularly his employment of the word pendent, which he spells "pendant." Pendent is a good example of Whitman's theory of 
words in practice. It draws attention to itself as an unusual word choice. It contains a variety of meanings, and Whitman draws upon all of them in one way or another. In one sense, it can mean "overhanging," either from above or "jutting or leaning over; sloping or slanting" (OED). This plays upon a common sense of ideas as floating above realities: the woman's fantasy floats like a cloud over the oblivious young men. Pendent is also derived from the word "dependent," which applies in the sense that the woman's imaginary body clings to and hangs from the young men. In yet another sense of the word, pendent means "remaining undecided or unsettled; pending, not progressing," capturing the woman's self-restraint. Therefore, the word pendent refers at once to the projection of desire and the restrained soul. It is a potent, full-bodied word, playing off multiple definitions and images, while referring to no one concept in particular. It is precise and meaningful, but vague and indefinite. The word as thing is like a gesture in that it conveys a peculiar, ineffable impression indivisible to any one referent. In this line, the qualities of the word pendent complement and enrich the qualities of the gesture in a well-rounded, suggestive image.

Another compelling example of Whitman's philosophy of words in application occurs in section 20 , when the speaker addresses a strange and ghostly presence:

Who goes there? Hankering, gross, mystical, nude;

How is it I extract strength from the beef I eat?

What is a man anyhow? What am I? What are you? (1-3).

In particular, I would like to consider the four adjectives in the first line- - "hankering, gross, mystical, nude." Adjectives modify a noun, but here it is not entirely clear what the noun is. The subject of the sentence is the "I" of the second line, so it seems most plausible that the speaker 
describes himself. However, at the same time, he addresses an unseen other-"who goes there?"- suggesting that the adjectives might refer to some unidentified, shadowy figure. At the line break, the reader is left with the impression that the speaker has been caught off guard by some mysterious presence that is "hankering, gross, mystical, nude." Within the context of Whitman's philosophy of language, it is possible that Whitman courts ambiguity here deliberately. Each word is charged with a number of meanings and associations. Because Whitman gives such a vague indication of what these adjectives describe, it is difficult to determine which meanings and associations to apply. Does "gross" mean thick, stout, excessive, or disgusting? Without definite referential coordinates, each word enters the mind along with its full entourage of significance and connotation. Because each word refers to no one thing in particular, its full wealth of meaning is undiminished. These four words play off one another in unexpected and interesting ways, constituting an evocative texture of image and quality. Nathanson himself notes that these adjectives are "delicately weighed" (375). Insofar as reference is obscured in its sheer diversity, these four words can be said to evoke indirectly the affective signature of their phantasmal object.

Nathanson thinks that in this passage the voice of the speaker addresses one of his many identities assumed over the course of the poem:

Gazing with an odd detachment on forms he imagines himself to be, the poet hints at their vulnerability, their relation to an outside or an other that remains unassimilated and unmastered. It is as if the fantasy of the body as phallic, as selfcontained and self-engendered, could not be played out without calling itself into 
question. That "Song of Myself" is nevertheless ready to celebrate this body is one measure of the poem's comic poise (375).

The speaker is constantly taking on new forms and declaring his own ubiquity and universality, while also asserting self-sufficiency. Here, Nathanson's Whitman stops and considers the contradictions of his own paradigm. Whitman cannot be everything and himself. Every form is also a limitation. Nathanson points out that Whitman can only assume one identity at a given moment, and therefore cannot truly embrace all things. Also, he is not truly self-sufficient. As Nathanson observes, identity only exists in relation to other identities.

This reading holds together on its own. Whitman's paradigm of the self as Nathanson sketches it out here is contradictory. The self cannot be both self-contained and universal. The problem lies in Nathanson's interpretation of the paradigm itself. Nathanson does not recognize the distinction Whitman draws between the real Me and the persona. Whitman does not try to reconcile universality and individuality as properties of a single coherent self. Instead, universality and individuality are conditions of two separate aspects of a single entity. The persona is fluid, speaking, and transmutable. The real Me is silent, self-contained, and isolated. As such, Whitman's conception of the self is not contradictory, at least not in the way Nathanson seems to think.

It also seems unlikely that the figure addressed here is one of Whitman's identifications. It is hard to ascribe to it any kind of identity because it has no determinate form. Another problem is that Whitman describes it as "mystical," and although identity, for Whitman, is a product of spiritual empathy, it is not in itself spiritual. Furthermore, Whitman consistently speaks from the perspective of the persona. Nowhere in the poem does he address his identity. 
There is, however, considerable evidence that the figure in question is the real Me. The real Me is unequivocally a mystical force. The real Me is also vague, elusive, ineffable. This explains why Whitman does not describe it directly, but only through the oblique suggestiveness of adjectives. Furthermore, the word "hankering" attests to the ever-unfulfilled voracity of the soul. This voracity is best described in one of Whitman's notebook entries: "Rapidly, an insatiable greediness grew within me for brighter hues; oh, brighter and stronger still. It seemed as if all that the eye could bear, were unequal to the fierce voracity of my soul for intense, flowing color" (Uncollected Poetry and Prose I, 256). Whitman describes the soul as constantly hungering after a world with which it can never truly meld. As Friedman points out, the "great metaphor" for the spiritual communion of the soul within nature is "the physical assimilation of experience like food” (451). Paul Zweig makes a similar observation: “"digestion' becomes the underlying figure for all learning and perception" (255), because the soul "digests" the spiritual qualities of other entities. As a person encounters new things over the course of a lifetime, the soul assimilates their metaphysical properties. This explains why, in the very next line, Whitman asks, "how is it I extract strength from the beef I eat?" Just as we take in food and convert it into energy without really becoming what we eat, so the soul incorporates spiritual essences without ever truly merging with nature. As Whitman beholds the mystery of the real Me, he wonders what he really is: "What is a man anyhow? what am I? what are you?"

Finally, this passage occurs immediately after one of Whitman's most intense engagements of the outside world:

This is the press of a bashful hand, this the float and odor of hair, This the touch of my lips to yours, this the murmur of yearning, 
This the far-off depth and height reflecting my own face,

This the thoughtful merge of myself, and the outlet again (19.7-10).

Once again, the sexual context is used as an analogy for spiritual communion. In this case, however, the speaking identity takes centre stage, while the real Me remains off to the side. Unlike the real Me, the ego comes into direct contact with nature, defined entirely by the act of perception. The identity is immersed in the beauty of nature. So when the empathic act comes to a close, the speaker suddenly becomes conscious of the secret something that holds back, the basic substance that prevents the absolute absorption of the self into nature: the real Me. This is why he addresses it as an intruder: "Who goes there?" He then proceeds to dwell upon this elusive and indeterminate otherness.

Near the end of section 33 occurs one of Whitman's most emphatic assertions of embodiment. As in sections 19-20, this thrilling identification is offset by a strange, shadowy aspect that observes from the side:

I am the hounded slave, I wince at the bite of the dogs,

Hell and despair are upon me, crack and again crack the marksmen, I clutch the rails of the fence, my gore dribs, thinn'd with the ooze of my skin, I fall on the weeds and stones, The riders spur their unwilling horses, haul close, Taunt my dizzy ears and beat me violently over the head with whip-stocks.

Agonies are one of my changes of garments, I do not ask the wounded person how he feels, I myself become the wounded 
person,

My heart turns livid upon me as I lean on a cane and observe (130-38).

Whitman watches a runaway slave taken down by hounds and thrashed. He claims to empathize so deeply that he becomes the slave. He feels as if he too were taken down and thrashed. His conscious mind is completely absorbed in the scene taking place before him. His identity is thoroughly infused with the suffering of the slave. And yet, at the very point when Whitman declares most forcefully the utter pervasiveness of his empathy, this oddly reserved presence quietly intrudes from the side, leaning on a cane. How can Whitman simultaneously identify utterly with another person, while also remaining remote, detached, and observant?

Karen Sanchez-Eppler examines this problem in detail:

If the body defines identity, then a poetics of embodiment remains a potent fantasy; if, on the other hand, identity can be transferred from one body to another, then a poetics of embodiment might be achievable, but would also be meaningless. As a defense against the obvious undesirability of either of these positions Whitman redefines his poetics of embodiment so that it simultaneously insists that identity inheres in the flesh, and that it is a matter of representation, infinitely mobile and ultimately indeterminate (944).

Essentially, Sanchez-Eppler tries to figure out how Whitman can assert an act of unmediated embodiment: Whitman claims to become the slave, to enter the slave's body and feel the lashes and the dog-bites. Whitman declares that his identity can leave his body and enter another's. Sanchez-Eppler argues that this is an impossible claim. Either identity and body are one, or identity and body are distinct. In either case, identity cannot be transferred from body to body. If 
body and identity were one, they could not be separated in the first place. If distinct, identity would have no real connection to physical being. It would be an abstract, floating ideality that could not attach itself to any physical form. Sanchez-Eppler sees Whitman as trying to resolve this contradiction by revising his conception of identity so that it is still integral to the body, but human beings are capable of imaginatively representing their own identities and those of others.

The problem with this reading is that it simply ends up at the original problem: Whitman claims an unmediated embodiment, not a mental representation of one. Sanchez-Eppler does not quite succeed in showing how Whitman can claim unmediated embodiment while staying true to Whitman's philosophy. Thomas Byers provides a better explanation. He observes that, for Whitman, "Transcendent reality is available to —indeed, exists at—each point. Not only God, but the individual soul, can be or go everywhere" (33). He finds a similar dictum in Emerson: "There is no fact in nature which does not carry the whole sense of nature" (32). The universal is contained in the particular. Or, as Whitman puts it himself, "all truths await in all things" (30.1). As such, at the spiritual level, there is ultimately no difference between self and other: "the poet... can achieve merger with others precisely because, on the level of spirit, their otherness and their separate experiences are no more than "changes of garments"” (40). All souls are, ultimately, off-shoots of the Over-soul, which arches over and contains all things. Whitman's soul, therefore, already contains the agonies and the slave, the bullets and the dogs, and these agonies are evoked when he apprehends the scene before him, sparking a new identity in the thrilling moment of apprehension. Whitman's empathy is so absorbing that he is utterly lost in the moment—but only for the moment. His identity assumes the trappings of agony only for the duration of the spectacle. After that, it returns to normal. 
The soul, therefore, remains essentially unassimilated. Sanchez-Eppler points out the "odd doubleness with which Whitman retains the distance and difference of the observer. As he leans on a cane and observes, Whitman simultaneously presents himself as object and subject, embodied and disembodied, the wounded person and the voice which describes that livid flesh" (944). Aside from that, she leaves this "odd doubleness" unexplained. However, within the context of Whitman's poetics as I have outlined it so far, this unobtrusive figure can be read as Whitman's real Me. While the speaker is subsumed in empathy, the real Me remains ultimately unpossessed. Since the real Me cannot be expressed in language, it expresses itself through gesture, leaning cryptically on a cane. This gesture could mean anything. The real Me could be tired, ill, sad, or disappointed. In any case, leaning on a cane seems like a somewhat dispassionate response, especially in comparison to the intensity of the speaker's experience. As such, the gesture serves to distance the real Me from Whitman's involvement, conveying only a vague hint of covert distinctness.

Whitman provides a final compelling glimpse of the real Me in the very last section of "Song of Myself":

The spotted hawk swoops by and accuses me, he complains of my gab and my loitering

I too am not a bit tamed, I too am untranslatable, I sound my barbaric yawp over the roofs of the world.

The last scud of day holds back for me, 
It flings my likeness after the rest and true as any on the shadow'd wilds, It coaxes me to the vapor and the dusk.

I depart as air, I shake my white locks at the runaway sun, I effuse my flesh eddies, and drift it in lacy jags (52.1-8). Whitman begins with a disavowal of language as a means of expression and representation. In response to the hawk's complaint, Whitman demeans his poetry to "gab and loitering." Bauerlein reads this as a sign that Whitman has become disillusioned with his own self-image:

In comparing his actual expressions to the ideal expression exemplified by the mute face of nature and verified by its affective power, Whitman downgrades, with varying degrees of self-deprecation, his poems to 'gab.' Nature becomes an antagonist, an archetypal author and expression... whose peremptory wholeness only reminds Whitman of his deficiency. (141-42)

Nature does not use language, and therefore remains whole. Nature has not entered linguistic reality, and therefore has not suffered the separation of self and self-image. The wholeness of nature reminds Whitman of his own "deficiency." Because his poetry has failed to fully manifest his personality, he distances himself from it, "downgrading" it to gab.

However, I am not sure the word "gab" carries such a negative connotation for Whitman, especially considering the reverence he has for other inexpressive utterances. Whitman's poetry is full of examples of how he does not consider inarticulate sounds meaningless at all: "the wild gander leads his flock through the cool night, / Ya honk he says ... / the pert may suppose it meaningless, but I listening close, / Find its purpose and place it up there toward the wintry 
sky" (14.1-4). For Whitman, just the sound of a duck's honk is profoundly meaningful in and of itself. Every sound, touch, and object is richer than any act of reference. When Whitman describes his poem as "gab" or a "barbaric yawp," (3), he is actually paying himself a compliment. He is claiming that his poem does not mean any one thing, and therefore contains a plurality of meanings that, in the totality of its scope, evokes the sublime.

Thoreau expresses a similar sentiment in Walden. He recalls mistaking the lowing of a cow for a band of musicians he had heard some time before:

At evening, the distant lowing of some cow in the horizon beyond the woods sounded sweet and melodious, and at first I would mistake it for the voices of certain minstrels by whom I was sometimes serenaded... I do not mean to be satirical, but to express my appreciation of those youths' singing, when I state that I perceived clearly that it was akin to the music of the cow, and they were at length one articulation of nature (163).

Thoreau claims that he does the minstrels a compliment by this error, because it goes to show that their music is as natural an articulation as the lowing of a cow. I suspect that Whitman is getting at something similar here. By comparing his poem to the screech of a hawk, he claims that his poem is not an artificial distortion of nature, but an extension of it. The poem is itself a natural object.

As Miller observes, 'Like the hawk, the poet is 'untranslatable,' incomprehensible except in his own language, upon his own terms" (35). When Miller refers to Whitman's “own language," he echoes a quotation from one of Whitman's notebooks: "Every soul has its own language. The reason why any truth which I tell is not apparent to you, is mostly because I fail of 
translating it from my language into" (quoted in Friedman, 454), and the sentence is cut short. Every soul is ineffable and distinct, and as such cannot be put into words. As a result, the poet tells us truths, and we cannot understand them because there is no common tongue that can adequately translate private experience. The poet can only express his inner character indirectly. In the next line, "the last scud of day holds back," as if waiting for Whitman to follow. The sun invites Whitman for a final spiritual communion. It "flings" Whitman's "likeness after the rest and true as any on the shadow'd wilds," casting his shadow on the ground behind him. Here, Whitman's imagery echoes a line from Nature: "all the uses of nature admit of being summed in one, which yields the activity of man an infinite scope... It always speaks of Spirit. It suggests the absolute. It is a perpetual effect. It is a great shadow pointing always to the sun behind us" (Emerson, 32). Just as all shadows point to the sun, so all uses of nature point towards the "absolute" transcendent reality. Emerson uses this same analogy in "Spiritual Laws": "Our philosophy is affirmative and readily accepts the testimony of negative facts, as every shadow points to the sun. By a divine necessity, every fact in nature is constrained to offer its testimony" (184). This second quotation occurs immediately after Emerson illustrates how inner character manifests itself in every detail of behaviour:

The great man knew not that he was great. It took a century or two for that fact to appear. What he did, he did because he must; it was the most natural thing in the world, and grew out of the circumstances of the moment. But now, everything he did, even to the lifting of his finger or the eating of bread, looks large, all-related, and is called an institution. 
Just as every shadow points always to the sun, so every subtle idiosyncrasy, every hint of movement or posture, is a subtle intimation of inner truth. In the first quotation, nature "suggests" but does not represent or explain the absolute. Nature and behaviour indirectly imply transcendent reality and inner character. Through this allusion to Emerson, Whitman closes with a final salute to his poetics of indirection. Just as the sun casts Whitman's shadow on the ground, so the force of Whitman's character casts vague outlines of itself in the form of poetry. This shadow is "as true" and alike with all the other shadows on the ground, meaning that Whitman's poem is itself a part of nature. The poem is an object that contains a spiritual essence of its own like anything else. As Peter Bellis puts it, "objects present themselves independently, apart from any action by the writer. The poet's speech is to have the same independent existence, as a natural act in itself" (78).

The sun "coaxes" Whitman "to the vapor and the dusk," and Whitman follows: "I depart as air... / I effuse my flesh in eddies, and drift it in lacy jags." As Nathanson observes, "His disseminating form... divides into air and grass, impalpable voice and compost of flesh" (405). Whitman's identity dissolves in the world around him, becoming indefinite as air. However, Nathanson neglects to point out that, in the middle of this transformation, something holds back. While Whitman describes his body evaporating into an ethereal substance, representing his absorption into nature, he also describes a separate body performing yet another enigmatic gesture: "I shake my white locks at the runaway sun" (7). In these two lines, Whitman splits, once again, into two distinct selves. The real Me shakes its hair as the sun retreats along with Whitman's conscious I. This is why Whitman describes the sun as "runaway" even while he follows it in the form of vapour. 
As usual, the real Me expresses itself only through ambiguous gesture. There is no definite meaning associated with shaking hair. The real Me could be expressing pretty much anything, and therefore it expresses nothing in particular. The gesture communicates only the quality of its own movement, serving to underscore the inaccessibility of the real Me to logical understanding and linguistic representation, while granting a subtle and indirect hint of Whitman's ineffable character.

Whitman's theory of indirection explains how he can declare "Song of Myself" an extension of his personality while denying himself representation. Whitman grants the reader glimpses of his inner character through the alternate guises of the real Me, the Me myself, the soul, and an unnamed, silent double. Because character is ineffable, Whitman avoids describing himself directly. Instead, he uses language and gesture in evocative, impressionistic ways. He uses words as things by activating multiple meanings and associations at once. In a similar vein, he dissociates gestures from any definite thought or feeling, so that each gesture becomes an object of inexhaustible contemplation. Within the context of Whitman's transcendentalism and theory of indirection, there is fairly compelling evidence that these words and gestures were meant to approximate or point toward some faint trace of Whitman's private character. 


\section{Bibliography}

Ackerman, Alan L. The Portable Theatre: American Literature \& the Nineteenth-century Stage. Baltimore (Md.): John Hopkins UP, 1999.

Allen, Gay Wilson. Walt Whitman Handbook. New York: Hendricks House, 1946.

Bauerlein, Mark. "Whitman's Language of the Self." American Imago 44.2 (Summer 1987).

-----------. Whitman and the American Idiom. Louisiana State University Press, 1991. 
Bellis, Peter J. Writing Revolution: Aesthetics and Politics in Hawthorne, Whitman, and Thoreau. University of Georgia Press, 2003.

Best, Stephen and Sharon Mercus. "Surface Reading: An Introduction." Representations. 108.1 (Fall, 2009) 1-21.

Byers, Thomas B. What I Cannot Say: Self, Word, and World in Whitman, Stevens, and Merwin. Urbana and Chicago: University of Illinois Press, 1989.

Bloom, Harold. Poetry and Repression. New Haven and London: Yale University Press, 1976.

Chari, V.K. “The Limits of Whitman's Symbolism.” Journal of American Studies, Vol. 5, No. 2 (August, 1971), 173-184.

Cheng, Anne. "Skin, Tattoos, and Susceptibility." Representations, 108.1 (Fall, 2009), 98-119.

Cummings, Glen. "Placing the Impalpable: Walt Whitman and Elias Hicks." Modern Language Studies 28.2 (Spring, 1998) 69-86.

Emerson, Ralph W. The Essential Writings of Ralph Waldo Emerson. New York: Modern Library, 2000.

Feidelson, Charles Jr. Symbolism and American Literature. Chicago: University of Chicago Press, 1953.

Friedman, Rohn S. "A Whitman Primer: Solipsism and Identity." American Quarterly, 27.4 (October, 1975), 443-460.

Hollis, C. Carroll. Language and Style in Leaves of Grass. Baton Rouge: Louisiana State University Press, 1983.

Irwin, John T. American Hieroglyphics. Baltimore: Johns Hopkins University Press, 1980.

Lewis, R.W.B. "Always Going Out and Coming In." Walt Whitman. Ed. Harold Bloom. New York: Chelsea House, 1985. 99-126.

Love, Heather. "Close Reading and Thin Description,” Public Culture 25.3 (Fall 2013).

Matthiesson, F. O. American Renaissance. New York: Oxford University Press, 1964.

McNeil, David. Gesture and Thought. Chicago and London: The University of Chicago Press, 2005. 
Marcus, Sharon. Between Women: Friendship, Desire, and Marriage in Victorian England. Princeton, 2007.

Miller, James E. A Critical Guide to Leaves of Grass. Chicago: University of Chicago Press, 1957.

Nathanson, Tenney. Whitman's Presence: Body, Voice, and Writing in Leaves of Grass. New York: New York University Press, 1992.

Pavis, Patrice and Biller-Lappin. "Problems of a Semiology of Theatrical Gesture." Poetics Today, 2.3 (Spring, 1981) 65-93.

Porte, Joel. In Respect to Egotism: Studies in American Romanticism. Cambridge: Cambridge University Press, 1991.

Rountree, Thomas J. "Whitman's Indirect Expression and Its Application to "Song of Myself."” PMLA, 73.5, Part 1 (December 1958), 549-555.

Sanchez-Eppler, Karen. “To Stand Between: A Political Perspective on Whitman's Poetics of Merger and Embodiment.” ELH, 56.4 (Winter, 1989), 923-949.

Schyberg, Frederik. Walt Whitman;. New York: Columbia UP, 1951.

Thoreau, Henry David. Walden. New York: Thomas Y. Cromwell Company, 1961.

Waskow, Howard J. Whitman: Explorations in Form. Chicago: University of Chicago Press, 1966.

Warren, James Perrin. Walt Whitman's Language Experiment. University Park: Pennsylvania State University Press, 1990.

Whitman, Walt. The Complete Poems of Walt Whitman. Ware: Wordsworth Poetry Library. 1995.

Prose Works. Philadelphia: David McKay, 1892; Bartleby.com, 2000. www.bartleby.com/229/.

------------. Daybooks and Notebooks. Eds. William White. New York University Press: 1977.

Uncollected Poetry and Prose. Ed. Emory Holloway. 2 vols. Garden City, New York: Doubleday, Page, 1921. Peter Smith, 1972. 
------------. Walt Whitman's Workshop A Collection of Unpublished Manuscripts. Ed. Clifton Joseph Furness. New York: Russell \& Russell, 1964. Print.

Zweig, Paul. Walt Whitman. New York: Basic Books Inc., 1984. 